\title{
Estimation of thermodynamic and dynamic contributions to sea ice growth in the Central Arctic using ICESat-2 and MOSAiC SIMBA buoy data
}

\author{
YoungHyun Koo ${ }^{\mathrm{a}}$, Ruibo Lei ${ }^{\mathrm{b}}$, Yubing Cheng ${ }^{\mathrm{c}}$, Bin Cheng ${ }^{\mathrm{d}}$, Hongjie Xie ${ }^{\mathrm{a}, *}$, Mario Hoppmann ${ }^{\mathrm{e}}$, \\ Nathan T. Kurtz ${ }^{\text {f }}$, Stephen F. Ackley ${ }^{\text {a }}$, Alberto M. Mestas-Nuñez ${ }^{a}$ \\ ${ }^{a}$ Department of Earth and Planetary Sciences, University of Texas at San Antonio, San Antonio, TX, USA \\ ${ }^{\mathrm{b}}$ Key Laboratory for Polar Science of the MNR, Polar Research Institute of China, Shanghai, China \\ ${ }^{\mathrm{c}}$ Institute of Atmospheric Physics, Chinese Academy of Sciences, Beijing, China \\ ${ }^{\mathrm{d}}$ Finnish Meteorological Institute, Helsinki, Finland \\ e Alfred-Wegener-Institut Helmholtz-Zentrum für Polar- und Meeresforschung, Bremerhaven, Germany \\ ${ }^{\mathrm{f}}$ Cryospheric Sciences Laboratory, NASA Goddard Space Flight Center, Greenbelt, MD, USA
}

\section{A R T I C L E I N F O}

\section{Editor: Dr. Menghua Wang}

\section{Keywords:}

Satellite altimeter

Remote sensing

Sea ice mass balance

Sea ice deformation

Ridge

Lead

\begin{abstract}
A B S T R A C T
The fine spatial resolution of the ICESat-2 (IS2) satellite altimeter allows monitoring the evolution of sea ice thickness with detailed dynamic information (e.g. ridges and leads). In this study, we first assess the ability of IS2 to estimate thermodynamic ice growth and dynamic thickening during the ice-growing season in the central Arctic Ocean. As an indicator of the thermodynamic ice growth, we use 10 thermistor string-based sea ice mass balance array (SIMBA) buoys deployed at a scale of $\sim 50 \mathrm{~km}$ from the Icebreaker Polarstern during the Multidisciplinary drifting Observatory for the Study of Arctic Climate (MOSAiC) expedition. We collect IS2 data within $20 \mathrm{~km}$ buffer distance from the individual buoys, and calculate the mode, median, and mean of the IS2-derived ice thickness. The IS2 modal thickness shows the least bias $(-0.169 \mathrm{~m})$ with the buoy ice thickness, representing level ice thickness. In addition, the increasing rate of the IS2 modal thickness is close to the thermodynamic ice growth with a small bias of $-0.054 \mathrm{~cm} /$ day. However, the increasing rates of the IS 2 median and mean thickness are greater than the thermodynamic ice growth by about $0.114 \mathrm{~cm} /$ day and $0.198 \mathrm{~cm} /$ day, respectively, because they also include ice growth caused by thickness redistribution during dynamic deformation. The dynamic contributions may account for $26.1 \pm 10.3 \%$ and $34.4 \pm 10.1 \%$ of the total increase of the IS 2 median and mean thickness, respectively. Within a $\sim 50 \mathrm{~km}$ radius area from the MOSAiC Central Observatory, IS2 measurements exhibit that the ridge fraction increased from $<2 \%$ in November to $\sim 4 \%$ in March $(\sim 0.029 \%$ /day of average increasing rate) and ridge height increased about $0.047 \mathrm{~cm} /$ day during the same period. However, lead formation does not show significant contributions to the dynamic ice thickening because leads are temporary features lasting only 2-3 days. Although there are considerable uncertainties in IS2 ice thickness estimation and IS2-buoy thickness comparison, this study emphasizes the importance of combining measurements by IS2 and SIMBA buoys to explain the regional sea ice mass balance with separating the thermodynamic and dynamic contributions.
\end{abstract}

\section{Introduction}

Sea ice extent (SIE) and sea ice thickness (SIT) in the Arctic Ocean have both decreased significantly over the last few decades. A decreasing trend of SIE was observed and has been maintained in recent years (Cavalieri and Parkinson, 2012; Meier, 2017; Simmonds, 2015; Stroeve and Notz, 2018). The decrease of SIT is also remarkable. The annual mean SIT decreased from 3.6 to $1.3 \mathrm{~m}$ from 1975 to 2012, a stunning drop of $65 \%$ (Lindsay and Schweiger, 2015), and the mean SIT in the melting season decreased by $2.0 \mathrm{~m}$ (66\%) from 1958 to 2018 (Kwok, 2018). Additionally, recent studies of satellite altimeters found a decreasing trend of Arctic SIT after a sudden increase of SIT in 2014 (Li et al., 2020; Tilling et al., 2018; Xiao et al., 2021, 2020). Given that the decline of SIE and SIT has profound impacts on the atmosphere (Budikova, 2009; Jaiser et al., 2012), oceanic circulation (Levermann et al., 2007), and both local and global climate (Liu et al., 2012; Screen, 2013),

\footnotetext{
* Corresponding author.

E-mail address: hongjie.xie@utsa.edu (H. Xie).
} 


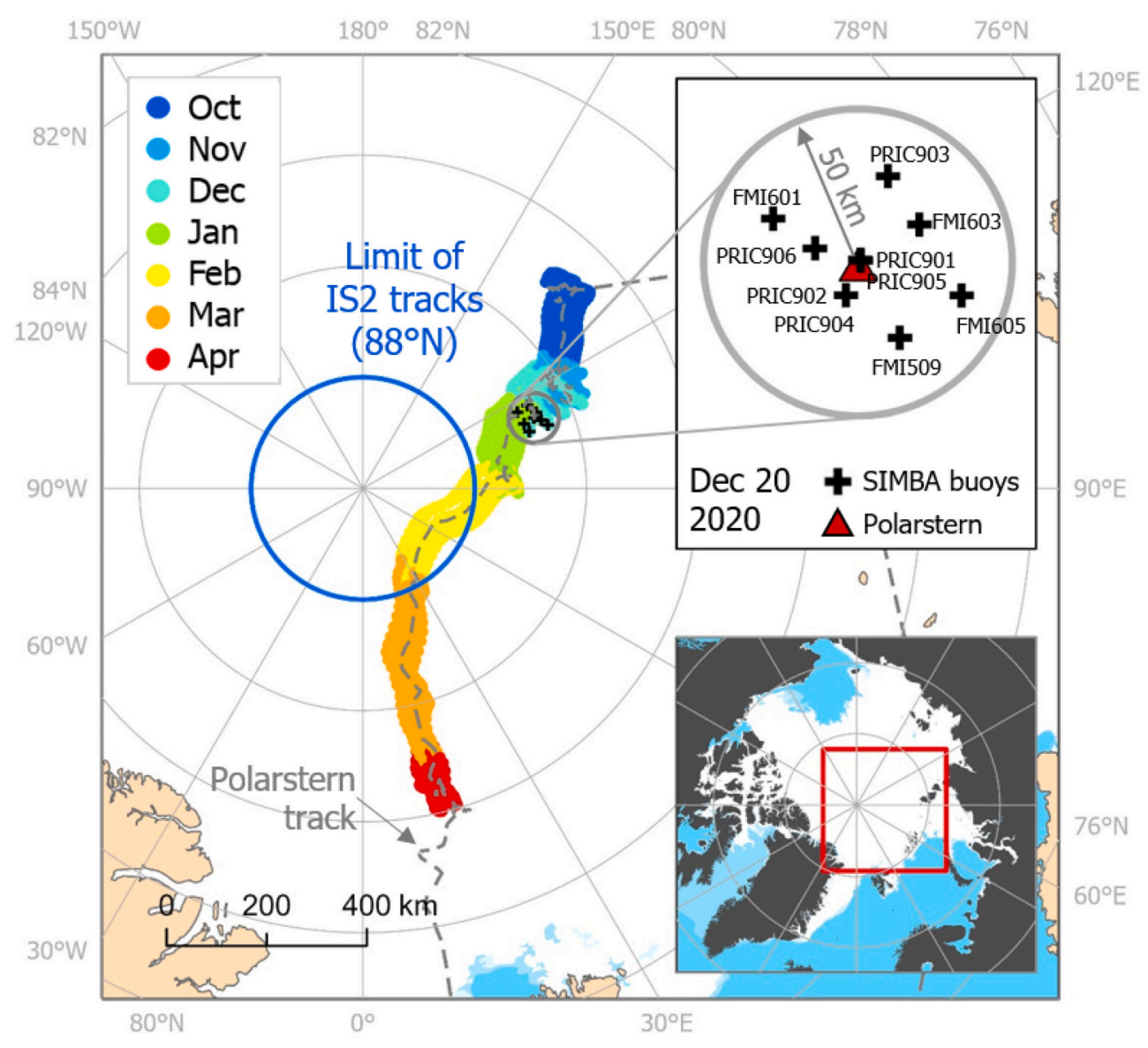

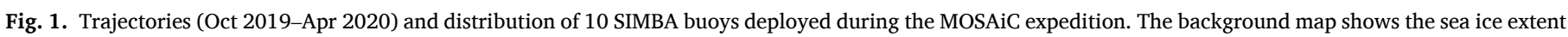

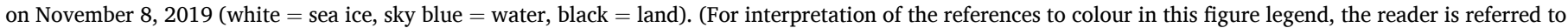
the web version of this article.)

a continuous monitoring of SIE and SIT is of great importance.

In this respect, spaceborne remote sensing has significant advantages to monitor SIE and SIT over the polar region regularly. However, it is more challenging to measure SIT from satellites than SIE because higher spatial resolution and precision are required for detecting SIT variability due to its relatively large spatial heterogeneity compared to SIE (Kwok, 2010). NASA (National Aeronautics and Space Administration)'s ICESat2 (IS2) is the latest satellite laser altimeter that makes this possible with advanced resolution and precision with a $\sim 12 \mathrm{~m}$ laser footprint (Magruder et al., 2020) and $\sim 2-4 \mathrm{~cm}$ of vertical precision (Kwok et al., 2019a). This high resolution and precision is particularly useful for detecting sea ice topography, such as pressure ridges, leads, and melt ponds (Farrell et al., 2020; Tilling et al., 2020). This eventually enables us to distinguish the thermodynamic contributions (freezing or melting) and dynamic contributions (formation of ridges by convergent movement or leads by divergent movement) to SIT variations. Accurate monitoring of the thermodynamic and dynamic behavior of sea ice in the Arctic is of large importance in understanding the total ice mass balance and its interaction with ocean, atmosphere, and climate change (Hibler, 1979; Itkin et al., 2018; Zhang et al., 2000). Although recent studies examined the Arctic SIT variations by using IS2 (Kwok et al., 2020a; Petty et al., 2020b) and validated that IS2 freeboard has only $<0.04 \mathrm{~m}$ of differences with the ATM (Airborne Topographic Mapper) freeboard of the Operation IceBridge (OIB) (Kwok et al., 2019a), the potential of IS2 to estimate thermodynamic and dynamic ice growth has not been clearly assessed.

In this study, the ability of IS2 for estimating thermodynamic and dynamic ice growth is assessed, with a focus on the central Arctic during the ice-growing season from late autumn to spring. For this purpose, thermistor string-based sea ice mass balance array (SIMBA) buoys deployed as a part of the Multidisciplinary drifting Observatory for the Study of Arctic Climate (MOSAiC) expedition are also used. A large number of SIMBA buoys were deployed to measure snow depth and SIT in the Arctic and Antarctic oceans (Hoppmann et al., 2015; Lei et al., 2018; Provost et al., 2019, 2017). Considering that airborne or shipborne measurements provide only snapshot observations and have limits on their data-collection periods (Wang et al., 2016), ice mass balance buoys (IMB) buoys, such as SIMBA buoys and the traditional IMB (Richter-Menge et al., 2006), are the most effective way for obtaining seasonal variations of SIT and thermodynamic ice growth (Ackley et al., 2020, 2015; Perovich et al., 2003). On the other hand, ice thicknesses and ice growth rates have a large spatial heterogeneity (Perovich et al., 2003), which cannot be completely captured by observations of the buoys deployed individually. This limited representativeness of a single point observation was an obstacle for using the previous SIMBA or other IMB buoys to identify the average state of changes in SIT caused by thermodynamic and dynamic processes at the local scale, and to verify the SIT measured by satellite altimeters.

In this respect, the MOSAiC expedition is an unprecedented opportunity to obtain homogeneous in-situ observations over the central Arctic Ocean (Shupe et al., 2020). As a year-round field expedition using the German research icebreaker Polarstern, the MOSAiC expedition provided massive in-situ observations over the central Arctic Ocean from September 2019 to October 2020. The SIMBA buoys, as a part of a distributed network (DN) of MOSAiC, were deployed in the region at a scale of $\sim 50 \mathrm{~km}$ from the Polarstern (Fig. 1). MOSAiC DN included both multi-year ice (MYI) and first-year ice (FYI), a good representation of sea ice under the new normal condition of the Arctic (Krumpen et al., 2020). 
Compared to the previous scattered buoys, the SIMBA buoys of the MOSAiC expedition can provide local-scale information of SIT over the study period.

Therefore, this study focuses on assessing the performance of IS2 for estimating the temporal changes of SIT over the central Arctic using MOSAiC SIMBA buoys data as a "ground truth". Based on the understanding of SIMBA measurements that show the thermodynamic ice growth, we evaluate the accuracy of IS2 for estimating SIT and its growth rate by comparing the IS2 measurements with the SIMBA buoys through later autumn to spring. Furthermore, by taking advantage of IS2's fine spatial resolution, we calculate the thermodynamic ice growth and dynamic ice thickening and their relative contributions to the SIT changes.

\section{Data}

\subsection{ICESat-2 data}

IS2's Advanced Topographic Laser Altimeter System (ATLAS) uses laser photons at $532 \mathrm{~nm}$ wavelength, with individual laser footprints of $\sim 12 \mathrm{~m}$ separated by $0.7 \mathrm{~m}$. It consists of three pairs of strong and weak beams, and strong beams have $\sim 4$ times greater pulse energies than weak beams (Magruder et al., 2020; Markus et al., 2017; Neumann et al., 2019). The improved spatial resolution of IS2 guarantees significant advantages for sea ice research compared to the previous ICESat altimeter that had footprints of $\sim 70 \mathrm{~m}$ with $170 \mathrm{~m}$ spacing (Zwally et al., 2002) or CryoSat- 2 radar altimeter that has $\sim 400 \mathrm{~m}$ of along-track footprint and $\sim 1.65 \mathrm{~km}$ of across-track footprint (ESA, 2019). In this study, we use the IS2 ATL10 sea ice freeboard product (release 003) from NASA's Earthdata (earthdata.nasa.gov).

The ATL10 freeboard product retrieves the surface heights by aggregating 150 ATL03 geolocated signal photons into a single height segment. Photon rate, width of photon distribution, and background rate were used to classify lead and ice for each height segment. Then the total freeboard was calculated by subtracting the local sea reference height from the surface height (Kwok et al., 2021). Given that strong beams have a better along-track resolution (10-200 m) than weak beams $(40-800 \mathrm{~m}$ ) for the surface heights estimation (Kwok et al., 2019b), here we only use the 3 strong beams. Since IS2 laser photons do not substantially penetrate the snow layer, herein the IS2 total freeboard represents the height of the air-snow interface above the sea level (Kwok et al., 2021; Kwok et al., 2020a).

\subsection{SIMBA buoy data}

We use the data from 10 SIMBA buoys that were deployed in the vicinity of the MOSAiC Central Observatory (CO) in October and November 2019. These buoys covered a spatial scale of about $50 \mathrm{~km}$ and exhibited similar drift patterns (Fig. 1). Since the floes of the CO and DN were formed around November to December 2018, the buoys were dominantly deployed at the area of second-year ice (Krumpen et al., 2021, 2020). The deployment sites had initial snow depth and ice thicknesses ranging from $0.05-0.30 \mathrm{~m}$ and $0.40-1.70 \mathrm{~m}$, respectively. The average initial snow depth $(0.16 \mathrm{~m})$ and ice thickness $(0.95 \mathrm{~m})$ over these buoy sites are close to the averages $(0.10 \mathrm{~m}$ and $0.84 \mathrm{~m})$ obtained from on-ice survey along the sections of 27.4-km using a ground-based electromagnetic induction and a magnaprobe over four ice stations of the MOSAiC DN (Krumpen et al., 2020). This suggests that the deployment sites of buoys have a high representativeness.

SIMBA is a thermistor string based IMB, and the vertical environment temperature (ET) profile was measured using a 4.8-m long string with embedded thermistors every $2 \mathrm{~cm}$. Each sensor was also equipped with a resistor component in order to determine the temperature rise (heating temperature, HT) after $60 \mathrm{~s} \mathrm{(HT1)} \mathrm{and} 120 \mathrm{~s}$ (HT2) after the pulsative heating (Jackson et al., 2013). The thermistor string was deployed vertically in a borehole through the snow and ice layer, so the
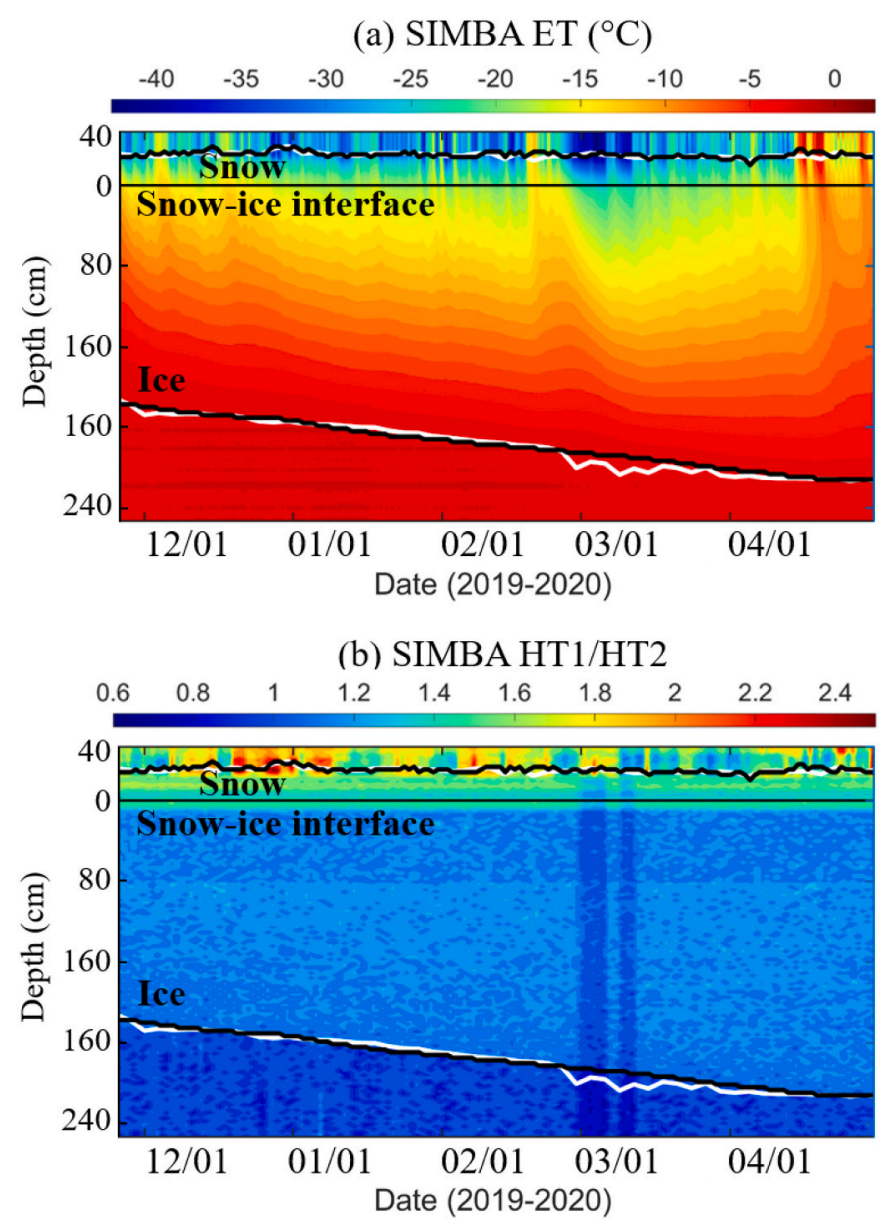

Fig. 2. (a) Time series of the SIMBA (FMI0601) environment temperature (ET) profile. (b) Time series of the SIMBA heating temperature (HT) ratio (HT1/HT2; $\mathrm{HT} 1=\mathrm{HT}$ at $60 \mathrm{~s}$ after pulsative heating, HT2 $=\mathrm{HT}$ at $120 \mathrm{~s}$ after heating). The white lines are results from the automatic algorithm and the black lines are results from the manual judgment.

temperature profiles in air, snow, ice, and water were measured. During the ice-growing season between November 2019 and April 2020, the buoys drifted along the Transpolar Drift Stream from north of the Laptev Sea to north of Fram Strait. It should be noted that SIMBA buoys drifted north of $88^{\circ} \mathrm{N}$, where IS2 has no valid data (inside the blue circle in Fig. 1), between late February and early March.

\section{Method}

\subsection{SIMBA buoys ice thickness}

From SIMBA buoys, we identify temporal variations of snow depth and ice thickness. The primary output from SIMBA buoys are the vertical ET or HT profiles, and various methods have been developed to extract snow depth and ice thickness from SIMBA measurements based on the difference of vertical gradient or daily amplitude of temperature and temperature rise after the pulse heating among air, snow and ice (Cheng et al., 2020; Liao et al., 2019; Zuo et al., 2018). In this study, we manually determine the snow depth and ice thickness from the temperature profiles based on the vertical ET gradient and vertical difference of HT1/HT2. The vertical ET gradient is the optimal criterion, and the heating data is used when the judgment by ET is not clear. We crosscheck this manual detection by using an automatic algorithm developed by Cheng et al. (2020). Our manual detection shows $\sim 3 \mathrm{~cm}$ deviation of snow depth and $\sim 5 \mathrm{~cm}$ deviation of ice thickness from the automatic method, while the manual method can effectively eliminate the 


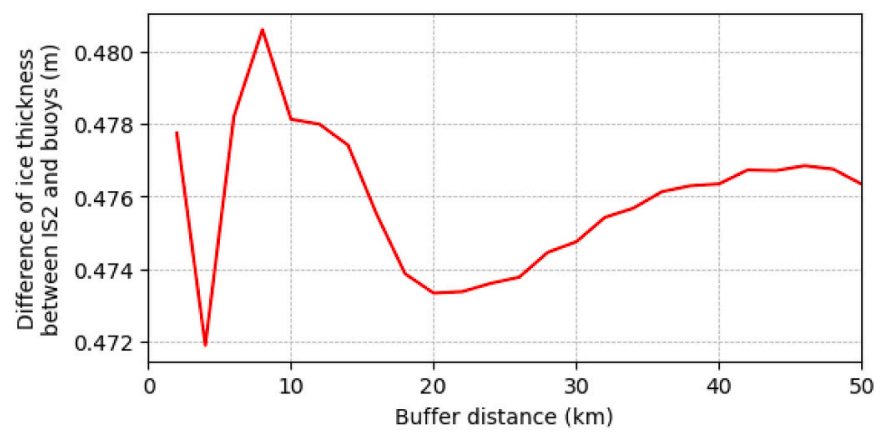

Fig. 3. Average differences of ice thickness between IS2 and SIMBA buoys for different buffer distances (every $2 \mathrm{~km}$ ). The buffer distance of $20 \mathrm{~km}$ has the minimum difference.

accidental noise brought by the automatic algorithm as shown in Fig. 2. Fig. 2 illustrates one example of SIMBA ET and SIMBA HT1/HT2, as well as the identified snow depth and ice thickness.

\subsection{IS2 ice thickness}

Since IS2 measures the total freeboard, this freeboard measurement should be converted to ice thickness to be compared with the buoy ice thickness. Assuming hydrostatic equilibrium, IS2 total freeboard is converted into sea ice thickness by using Eq. (1):

$h_{i}=\frac{\rho_{w}}{\rho_{w}-\rho_{i}} h_{f}+\frac{\rho_{s}-\rho_{w}}{\rho_{w}-\rho_{i}} h_{s}$

where $h_{f}$ is total freeboard measured by IS2, $\rho_{w}$ is the density of water, $\rho_{i}$ is the density of ice, $\rho_{s}$ is the density of snow, and $h_{s}$ is the snow depth. Since there are no individual density measurements for the buoys, we assume $1025 \mathrm{~kg} / \mathrm{m}^{3}, 900 \mathrm{~kg} / \mathrm{m}^{3}$, and $300 \mathrm{~kg} / \mathrm{m}^{3}$ for $\rho_{w}, \rho_{i}$, and $\rho_{s}$, respectively, based on the field measurements at the MOSAiC CO and previous studies (Alexandrov et al., 2010; Kwok and Cunningham, 2015; Laxon et al., 2003, 2013; Lindsay and Schweiger, 2015). For the snow depth $\left(h_{s}\right)$ in Eq. (1), we use linear equations from Kwok et al., 2020a to directly convert IS2 total freeboard into snow depth. Although each SIMBA buoy measures snow depth individually, this represents only local snow depth at the buoy deployment site but does not represent larger snow depth near rough sea ice topography (i.e. ridges or hummock) (Shalina and Sandven, 2018). Since herein the IS2 ice thickness should include both level ice and ice with the topographical changes, IS2 ice thickness is calculated by only using the IS2 total freeboard and selfretrieved snow depth from Kwok et al., 2020a method.

\subsection{Comparison of satellite and buoy ice thickness}

In this study, the IS2-retrieved ice thickness is compared with the buoy ice thickness within a representative buffer distance; we set this buffer distance to be $20 \mathrm{~km}$. In general, we should obtain lower thickness differences between IS2 and buoy for a shorter buffer distance. However, if this distance is too short, the number of overlapped satellite tracks is not sufficient to represent the temporal variations of ice thickness around the buoys. In addition, since the ice floe of the MOSAiC CO shows $10.35 \pm 6.22 \mathrm{~km}$ per day of average displacement during the study period, the buffer distance less than $\sim 10 \mathrm{~km}$ can cause a spatiotemporal discrepancy between IS2 sampled tracks and buoy sites. Fig. 3 shows the average differences of ice thickness between IS2 and buoys for buffer distances from 2 to $50 \mathrm{~km}$; IS2 and buoy points are paired if they have $<12 \mathrm{~h}$ of time gaps. It is noted that $5-15 \mathrm{~km}$ of buffer distance shows a higher difference, which may be attributed to the drift of ice floes between the acquisition times of IS2 and buoy data. Since $20 \mathrm{~km}$ shows the minimum differences after this $5-15 \mathrm{~km}$ range, we collect the IS2 data points that are located within $20 \mathrm{~km}$ from the buoys and with time gaps less than $12 \mathrm{~h}$ from the buoys.

After collecting the IS2 data within a $20 \mathrm{~km}$ radius around the buoys, three statistical parameters of IS2-derived freeboard and ice thickness are calculated within this buffer distance: mean, median, and mode. For example, as shown in Fig. 4, there is one IS2 track within the $20 \mathrm{~km}$ distance from the buoy PRIC0905 on November 13, 2019 and March 30, 2020. After the IS2 data points within the buffer are selected, the mean, median, and modal freeboard and ice thickness are calculated. Since the modal thickness represents the thickness of the most frequently observed ice or level ice (Farrell et al., 2012; Hansen et al., 2013; Petty et al., 2016; Rack et al., 2021; Tian et al., 2020), we estimate the thermodynamic ice growth around the buoys by using the variations in the modal thickness. On the other hand, since the mean and median thickness potentially include the thickness of ridged or deformed ice, we estimate the contributions of dynamic topographical changes to the IS2 mean and median thickness.

In order to quantitatively compare the IS2 measurements with buoy measurements, two factors between them are calculated: root mean square difference (RMSD) and mean biased difference (MBD). RMSD and MBD are defined by Eqs. (2) and (3), respectively.

$R M S D=\sqrt{\frac{1}{n} \sum_{i=1}^{n}\left(x_{I S 2}-x_{\text {buoy }}\right)^{2}}$

$M B D=\frac{1}{n} \sum_{i=1}^{n}\left(x_{I S 2}-x_{\text {buoy }}\right)$

where $x_{I S 2}$ is the IS2 measurement, $x_{\text {buoy }}$ is the buoy measurement, and $n$ is the number of comparison pairs. The relative RMSD and MBD can be also calculated as a percentage by dividing them with the mean of the buoy measurements. The accuracy of the IS2-derived SIT and ice growth are evaluated from these factors.

Additionally, to quantify the dynamic contributions to sea ice thickness, we calculate ridge fractions, lead fractions, and ridge heights based on the IS2 freeboard measurements. According to Farrell et al. (2020), pressure ridges can be defined as the parts with freeboard $0.6 \mathrm{~m}$ above the level sea ice. This $0.6 \mathrm{~m}$ threshold distinguishes ridges from lower-amplitude surface features such as snow dunes or sastrugi (Duncan et al., 2020, 2018; Farrell et al., 2020; Tan et al., 2012). Thus, the sea ice segments above $0.6 \mathrm{~m}$ from the modal freeboard are regarded as ridges, and the ridge fraction is then calculated (Fig. 5). Similar to the ridge fraction, we calculate lead fraction from the detected leads from the ATL10 products.

Ridge fraction $=\frac{L_{\text {ridge }}}{L_{\text {total }}} \times 100(\%)$

Lead fraction $=\frac{L_{\text {lead }}}{L_{\text {total }}} \times 100(\%)$

where $L_{\text {ridge }}$ is the summed length of all ridges in the IS2 track, $L_{\text {lead }}$ is the summed length of all leads in the IS2 track, and $L_{\text {total }}$ is the total length of the IS2 track (Fig. 5). To obtain $L_{\text {lead }}$ we use the leads detected by the ATL10 product. The ATL10 product determines leads from the decisiontree algorithm based on photon rate, width of photon distribution, and background rate (Kwok et al., 2019b). However, it should be noted that this lead detection algorithm shows limitations in detecting dark leads so the ATL10-based lead fraction could have been underestimated (Kwok et al., 2020b; Petty et al., 2020a). In addition to the ridge fraction and lead fraction, we calculate the changes of ridge heights $\left(H_{\text {ridge }}\right)$, which represent the mean heights of ridges above the level ice surface (Fig. 5). The ridge fraction, lead fraction, and ridge height are regarded as the indicators of dynamic sea ice deformation along the IS2 track. 

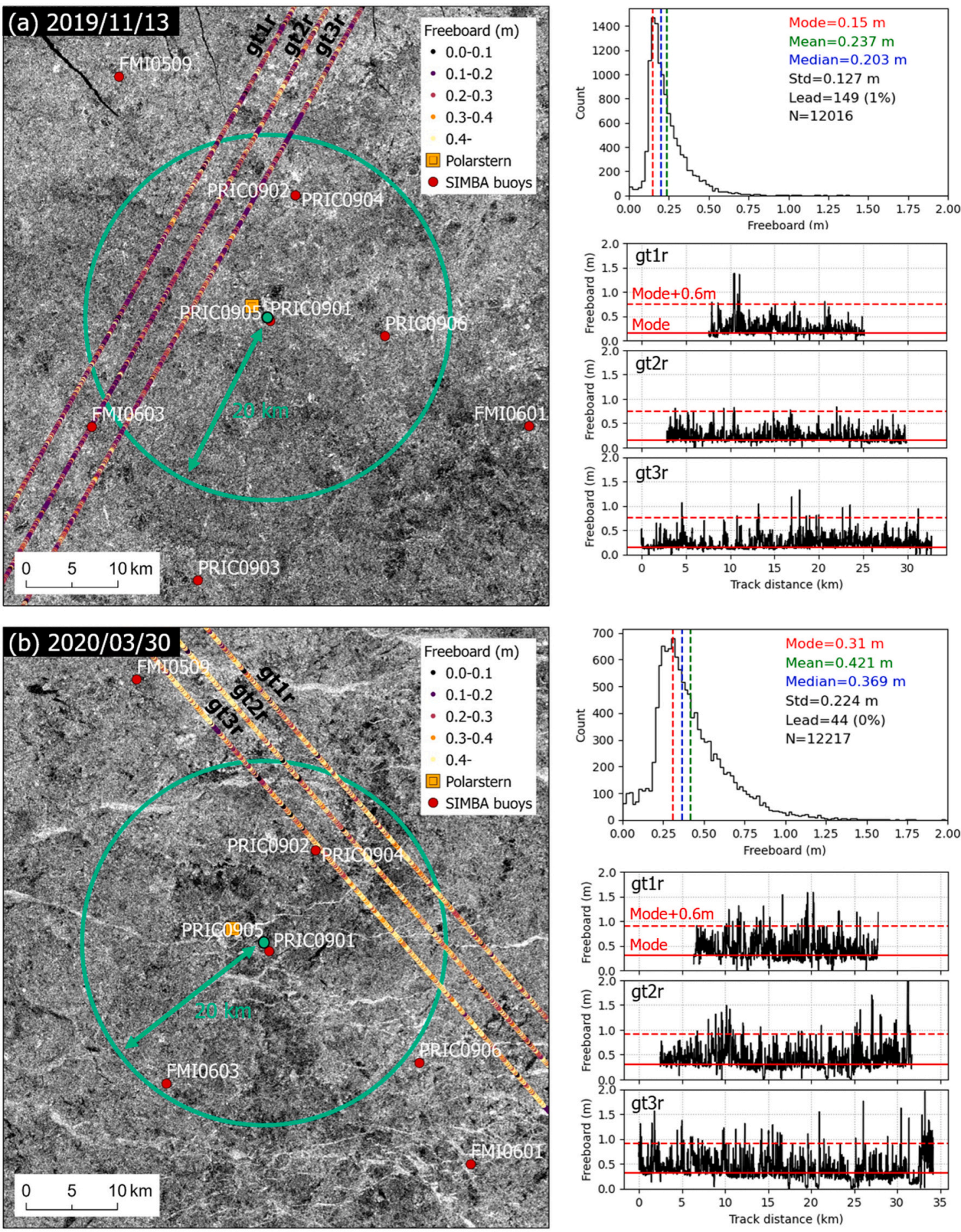

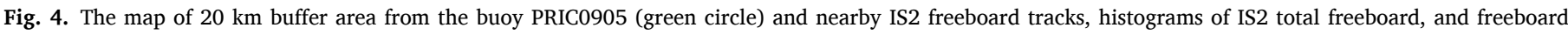

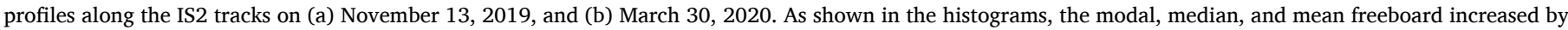

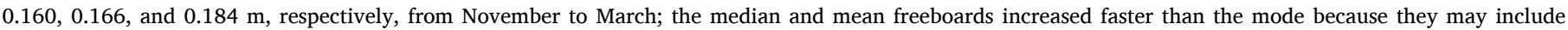

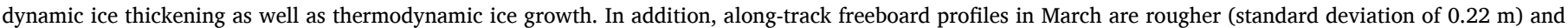

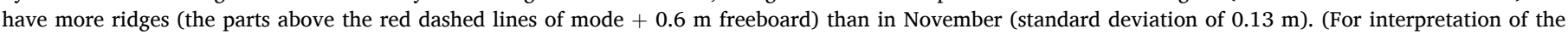
references to colour in this figure legend, the reader is referred to the web version of this article.)

\section{Results}

\subsection{Temporal variations of buoy measurements}

Snow depth and ice thickness determined using the measurements from all buoys are plotted in Fig. 6. The snow depth (Fig. 6a) is almost consistent from November to April for most buoys, ranging from $0.07 \mathrm{~m}$ to $0.29 \mathrm{~m}$. However, large snow accumulations are observed in early February for buoy PRIC0902 and PRIC0904. This snow accumulation of approximately $0.1 \mathrm{~m}$ in early February was likely due to a snow-storm event. Since these buoys were deployed close to a ridge with a relatively large surface roughness, blowing snow could be more 


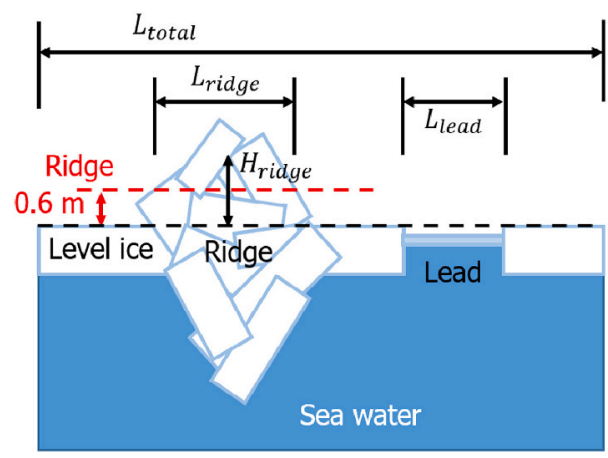

Fig. 5. Diagram of the ridge length $\left(L_{\text {ridge }}\right)$, lead length $\left(L_{\text {lead }}\right)$, effective IS2 track length $\left(L_{\text {total }}\right)$, and ridge height $\left(H_{\text {ridge }}\right)$.

accumulated near these buoys.

In terms of the ice thickness (Fig. 6b), all buoys show a monotonically increasing trend from November to April. On the starting dates in November, the ice thickness at the buoys ranged from 0.41 to $1.67 \mathrm{~m}$, while in mid-April, the thickness ranged from 1.54 to $2.27 \mathrm{~m}$, with a total increase of $0.50-1.20 \mathrm{~m}$. In order to check if these ice growths resulted from thermodynamic growths, we compare the measured ice growths with the ice growths estimated by an analytic model based on Stefan's Law (Leppäranta, 1993). In the presence of the snow layer above ice, the thermodynamic ice growth $(\mathrm{dH} / \mathrm{dt})$ can be expressed by following:

$\rho_{i} \mathrm{~L} \frac{\mathrm{dH}}{\mathrm{dt}}=\frac{\kappa_{i}\left(T_{f}-T_{s}\right)}{H+\left(\kappa_{i} / \kappa_{s}\right) h}$

where $\kappa_{i}$ is the heat conductivity of ice (assuming $2.3 \mathrm{~W} / \mathrm{m} \bullet \mathrm{K}$ ), $\kappa_{s}$ is the heat conductivity of snow (assuming $0.3 \mathrm{~W} / \mathrm{m} \bullet \mathrm{K}$ ) (Lecomte et al., 2013; Sturm et al., 2002b), L is the latent heat of freezing (assuming $334 \mathrm{~kJ} /$ kg) (Leppäranta, 1993; Park et al., 2020), $T_{f}$ is the freezing temperature at the bottom, $T_{s}$ is the snow surface temperature, $\mathrm{H}$ is ice thickness, and $\mathrm{h}$ is snow depth.

Based on the Eq. (6), we calculate the modeled ice growths over the ice-growing season using the vertical temperature profiles of the buoys, and compare them with the measured ice growths (Fig. 7). Since the ice growths measured by the 10 SIMBA buoys agree well with the modeled ice growths, we conclude that the buoy ice growths are caused by thermodynamic effects with negligible contributions from dynamic ice thickening and the formations of snow ice or superimposed ice.

\subsection{Temporal variations of IS2 thickness}

The temporal changes in IS2-derived ice thickness related to individual buoys are described in Fig. 8. As similar to the monotonic increase trend of the buoy ice thickness, the corresponding IS2-derived ice thickness also increased near linearly from November 2019 to April 2020. Although IS2 captures the increase in the ice thickness successfully, IS2 ice thickness shows some differences with the buoy ice thickness (Table 1). The IS2 modal thickness shows the least differences with the buoy thickness (RMSD $0.341 \mathrm{~m}$ and MBD $-0.169 \mathrm{~m}$ ), followed by the IS2 median and mean thickness. While the IS2 median and mean

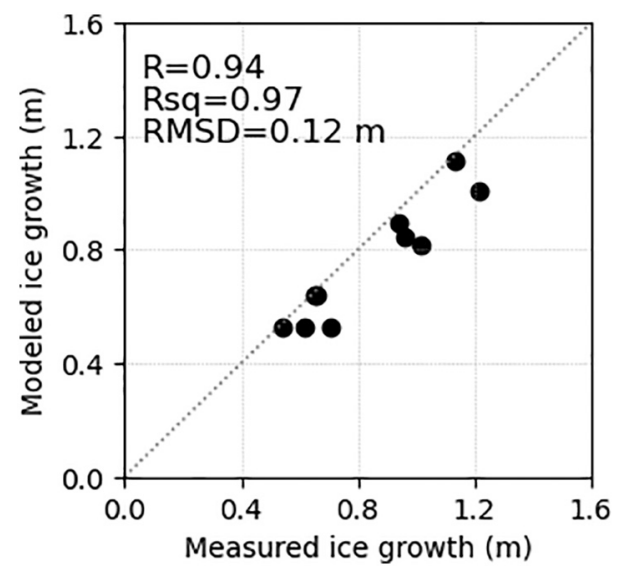

Fig. 7. The ice growths of 10 SIMBA buoys measured by buoy temperature profiles and modeled by Stefan's Law (Leppäranta, 1993).
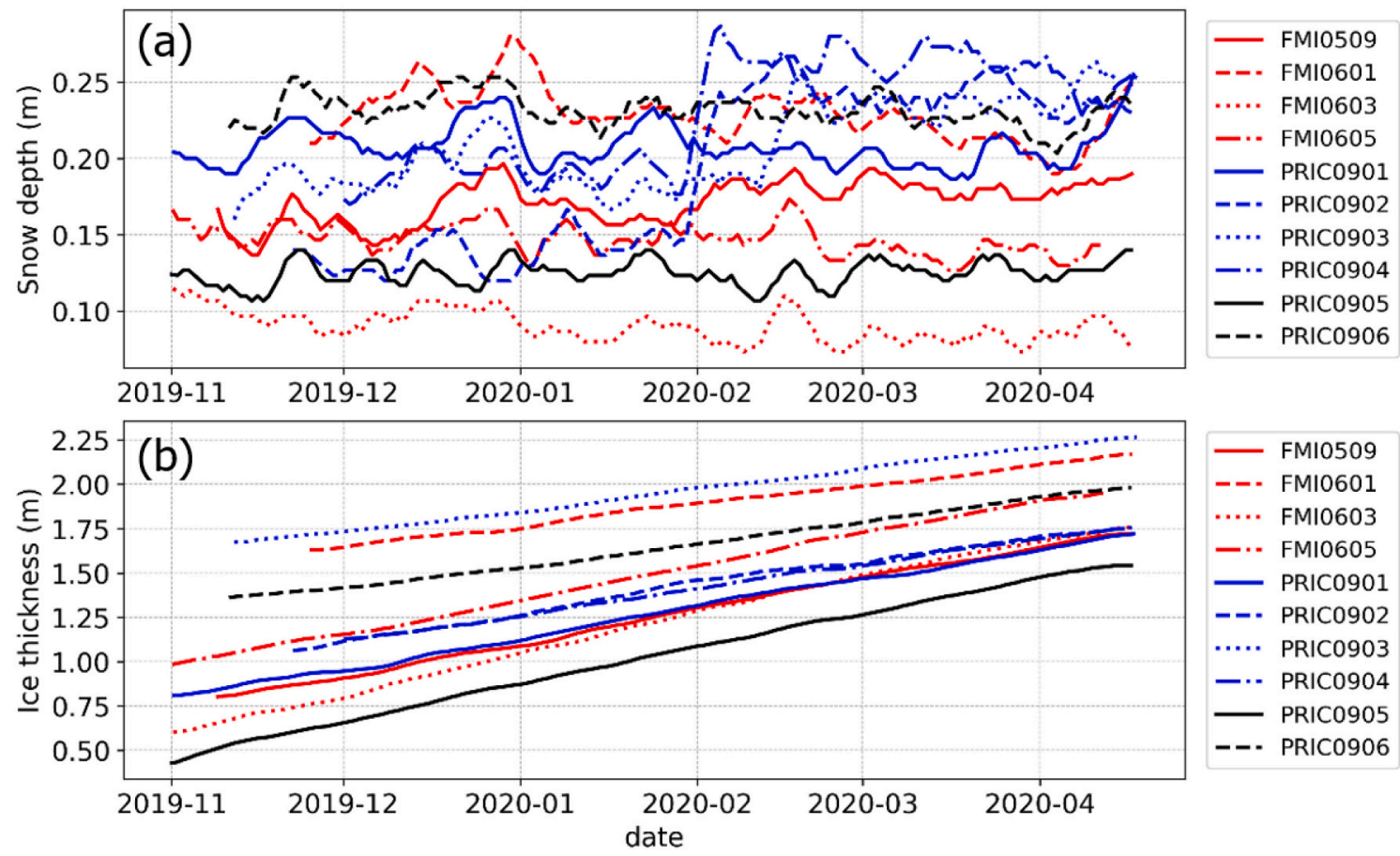

Fig. 6. Temporal variations of (a) snow depth and (b) ice thickness obtained from 10 SIMBAs deployed during the MOSAiC expedition. 
(a) Ice thickness (m)

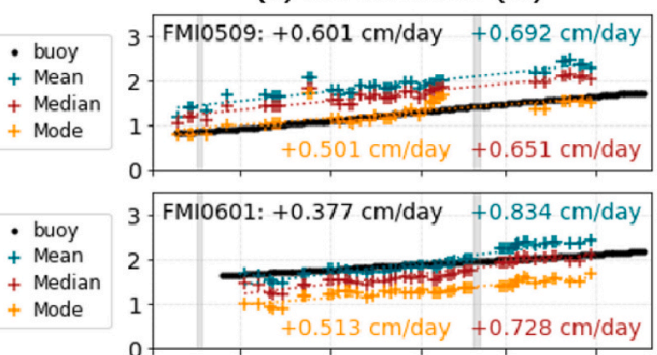

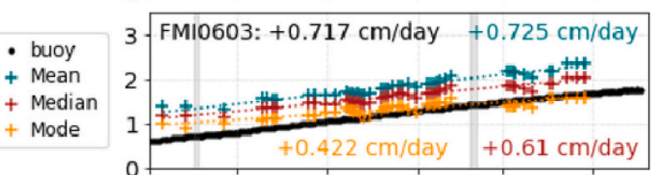

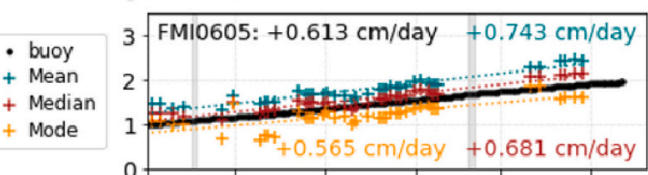

- buoy $3-$ PRIC0901: $+0.552 \mathrm{~cm} /$ day $+0.648 \mathrm{~cm} /$ day

+ Mean

+ Median

- Mode
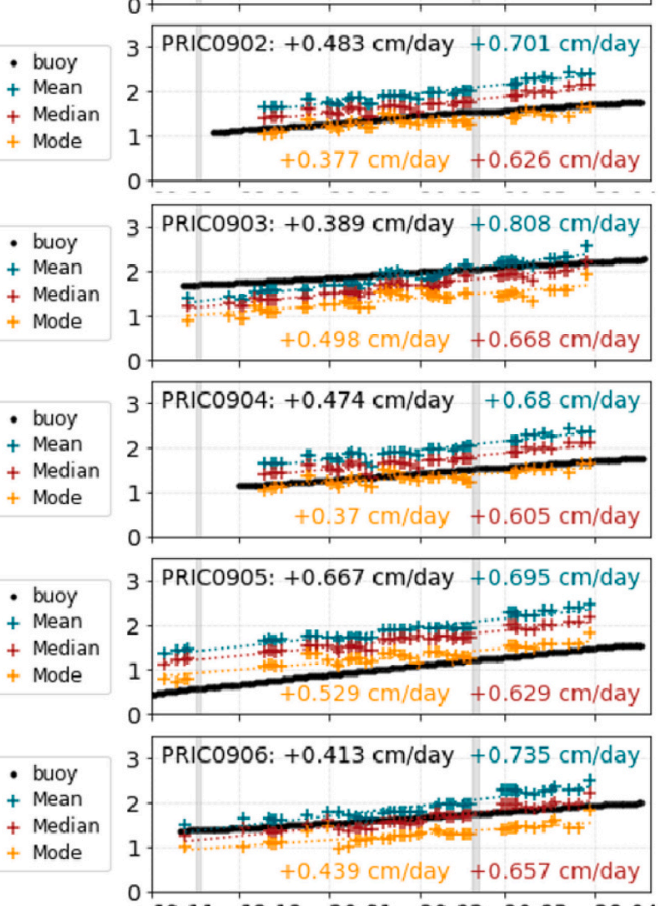

(b) Ridge/lead fraction (\%)
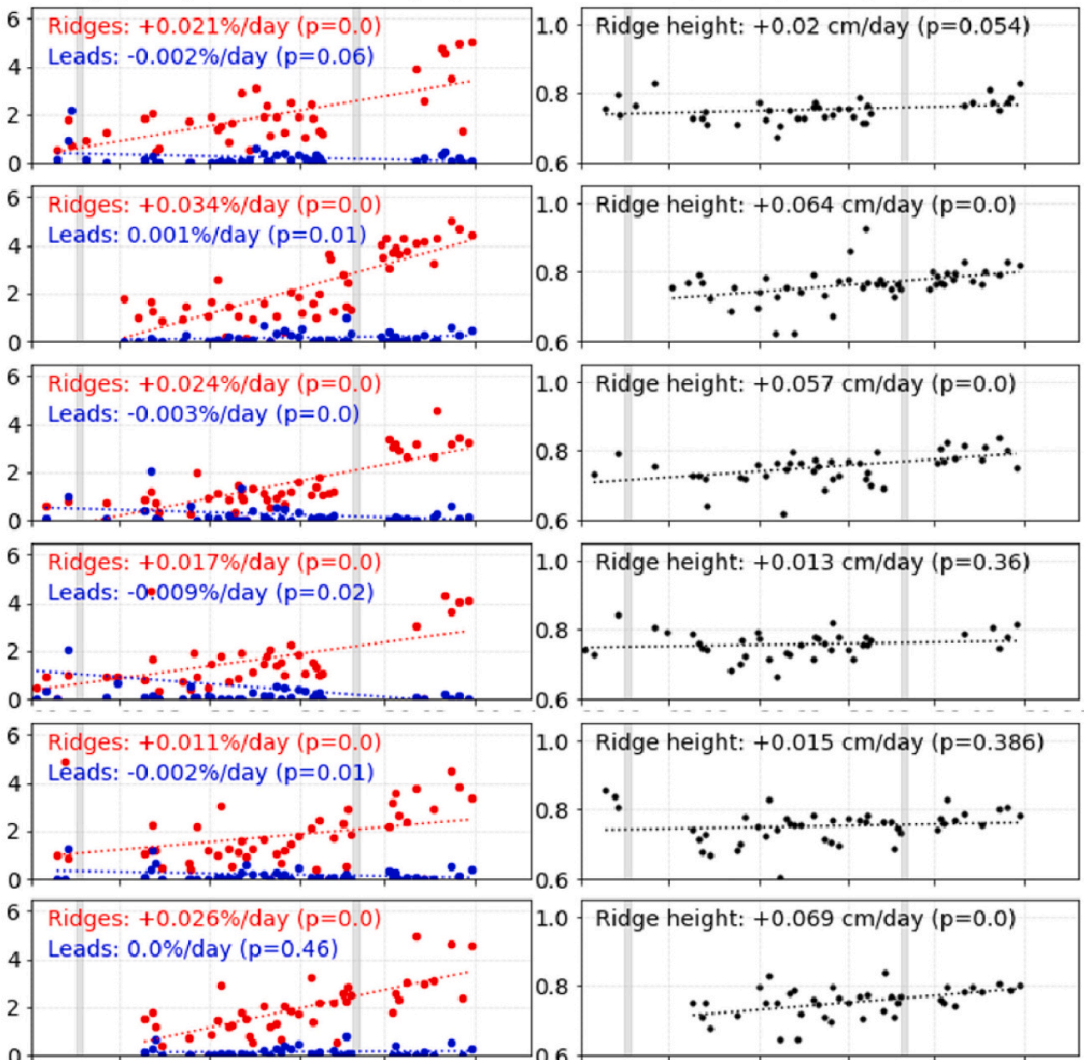

1.0 Ridge height: $+0.069 \mathrm{~cm} /$ day $(\mathrm{p}=0.0)$
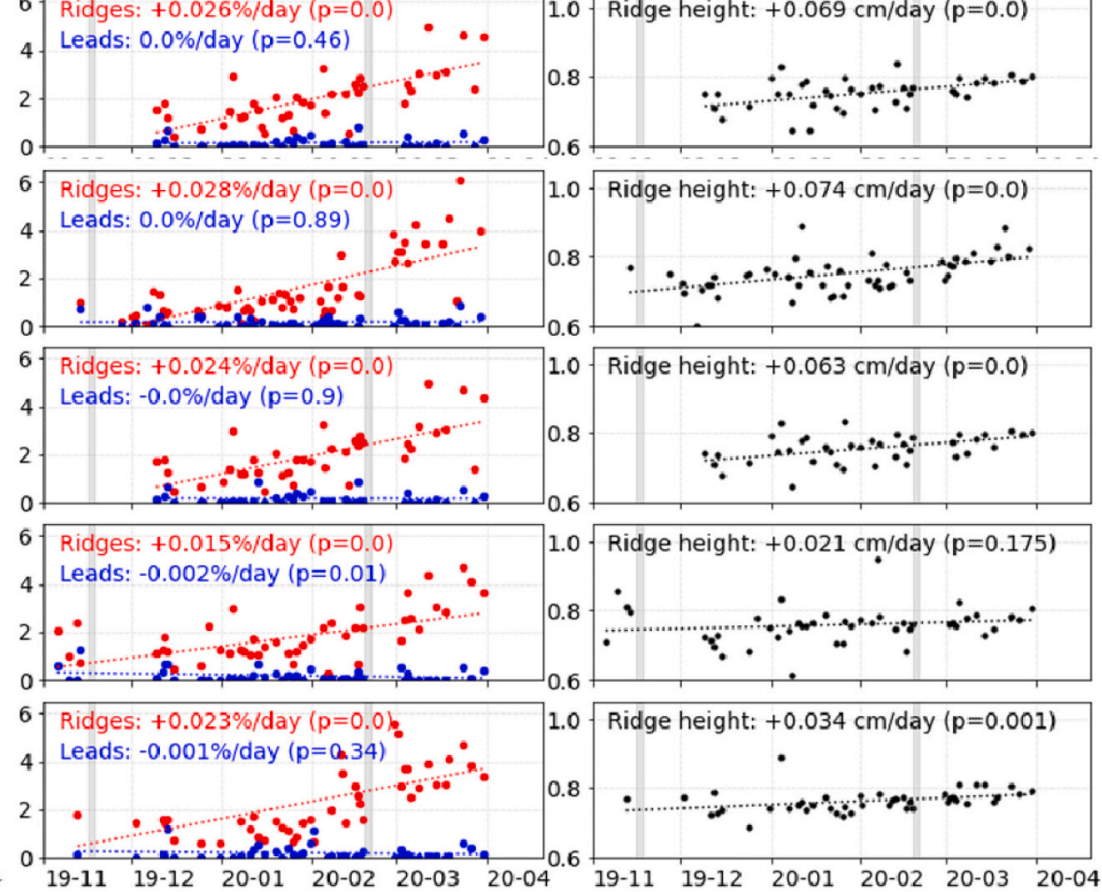

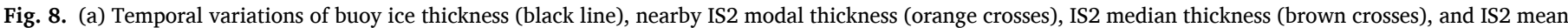

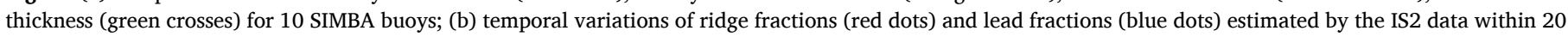

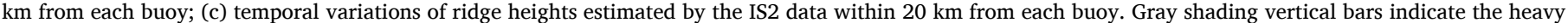

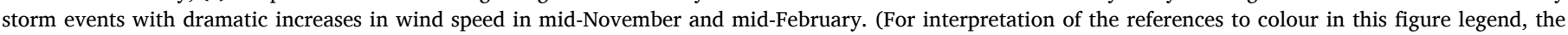
reader is referred to the web version of this article.)

Table 1

Overall RMSD and MBD of ice thickness between the IS2 measurements and the SIMBA buoys.

\begin{tabular}{lll}
\hline Ice thickness & RMSD & MBD \\
\hline IS2 mode & $0.341 \mathrm{~m}(23.3 \%)$ & $-0.169 \mathrm{~m}(-11.6 \%)$ \\
IS2 median & $0.359 \mathrm{~m}(24.6 \%)$ & $+0.190 \mathrm{~m}(13.0 \%)$ \\
IS2 mean & $0.531 \mathrm{~m}(36.4 \%)$ & $+0.433 \mathrm{~m}(29.7 \%)$ \\
\hline
\end{tabular}

measurements overestimate ice thickness (positive MBDs), the IS2 mode underestimates (negative MBD). Given that the ice thickness measured by the SIMBA buoys represents level ice, it is reasonable that the IS2 modal thickness is the closest to the buoy measurement. On the other hand, the median and mean IS2 thicknesses are greater than the buoy thickness because both of them also include the contribution of dynamic sea ice deformation (i.e. ridges).

Based on the IS2 ice thickness measurements, we calculate linearly- 
Table 2

Overall RMSD and MBD between the ice growth rate (November-April) from the IS2 measurements and the thermodynamic ice growth from the SIMBA buoys.

\begin{tabular}{lll}
\hline Ice growth & RMSD & MBD \\
\hline IS2 mode & $0.131 \mathrm{~cm} /$ day $(24.8 \%)$ & $-0.054 \mathrm{~cm} /$ day $(-10.3 \%)$ \\
IS2 median & $0.179 \mathrm{~cm} /$ day $(33.8 \%)$ & $+0.114 \mathrm{~cm} /$ day $(+21.6 \%)$ \\
IS2 mean & $0.248 \mathrm{~cm} /$ day $(46.9 \%)$ & $+0.198 \mathrm{~cm} /$ day $(+37.4 \%)$ \\
\hline
\end{tabular}

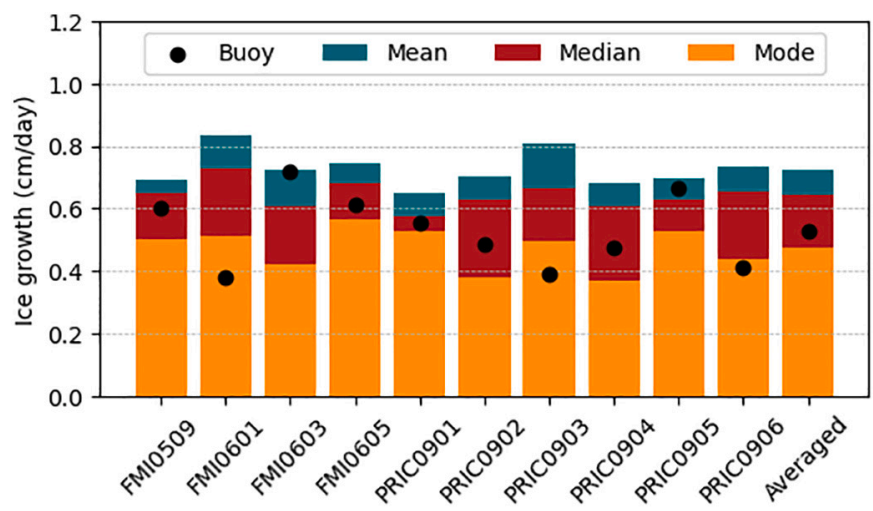

Fig. 9. Ice growth rate from November to April estimated by buoys and IS2 (mode, median, and mean) corresponding to each buoy.

fitted ice growth rate from each IS2 measurement and compare it with the thermodynamic ice growth from the buoys (Table 2). The ice growth estimated from IS2 modal thickness shows the least difference with the thermodynamic ice growth (RMSD $0.131 \mathrm{~cm} /$ day and MBD $-0.054 \mathrm{~cm}$ / day). However, the ice growth measured by the median and mean IS2 thicknesses are greater than the thermodynamic ice growth by more than double of the mode estimation bias $(+0.114 \mathrm{~cm} /$ day and +0.198 $\mathrm{cm} /$ day of MBD, respectively). Hence, the modal IS2 thickness represents the thermodynamic ice growth, but the median or mean IS2 thickness includes both the thermodynamic and dynamic contributions.

By comparing the IS2 median and mean increasing rates with the IS2 mode increasing rate, we quantify the contributions of dynamic deformation to the IS2 median and mean thickness. As shown in Fig. 9, the median and mean IS2 increasing rates are greater than the mode by 0.17 $\pm 0.07 \mathrm{~cm} /$ day and $0.25 \pm 0.08 \mathrm{~cm} /$ day, respectively. This implies that the dynamic thickening by sea ice deformation (i.e. increase of ridge fraction and ridge height) accounts for about $26.1 \pm 10.3 \%$ and $34.4 \pm$ $10.1 \%$ of the total thickness increase for the median and mean, respectively; the mean includes more dynamic contributions than the median.
Table 3

Comparison of ice thickness and ice growth between the IS2 measurements within a $50 \mathrm{~km}$ buffer from the center of MOSAiC DN and the average of the 10 SIMBA buoys.

\begin{tabular}{llll}
\hline $\begin{array}{l}\text { IS2 } \\
\text { measurements }\end{array}$ & $\begin{array}{l}\text { RMSD of ice } \\
\text { thickness }\end{array}$ & $\begin{array}{l}\text { MBD of ice } \\
\text { thickness }\end{array}$ & $\begin{array}{l}\text { Ice growth rate } \\
\text { relative to the buoy- } \\
\text { average }\end{array}$ \\
\hline IS2 mode & $0.154 \mathrm{~m}(10.4 \%)$ & $\begin{array}{l}-0.150 \mathrm{~m} \\
(-10.1 \%)\end{array}$ & $-0.088 \mathrm{~cm} /$ day \\
IS2 median & $0.214 \mathrm{~m} \mathrm{(14.4 \% )}$ & $\begin{array}{l}+0.208 \mathrm{~m} \\
(14.0 \%) \\
+0.449 \mathrm{~m} \\
(30.3 \%)\end{array}$ & $+0.148 \mathrm{~cm} /$ day \\
IS2 mean & $0.456 \mathrm{~m} \mathrm{(30.7 \% )}$ & $+0.244 \mathrm{~cm} /$ day \\
\hline
\end{tabular}

Indeed, as shown in Fig. 8b, the ridge fraction increased from November 2019 to April 2020 for all the buoys. In late autumn to early winter, ridged ice accounts for a smaller portion $(<2 \%)$ of the sea ice cover. As the sea ice becomes packed together during the ice-growing season, however, the proportion of ridged ice reaches to approximately $4 \%$. Whereas the ridge fractions increase, lead fraction does not show any significant increase or decrease trends because the opening due to the lead formation would refreeze soon during winter under the cold atmospheric forcing. In terms of the ridge height (Fig. 8c), while the IS2 measurements at four sites (FMI0509, FMI0605, PRIC0901, and PRIC0905) do not show significant increases (p-value $>0.05$ ), those at other six sites show significant increases in ridge heights (p-value $<$ 0.05). Therefore, the higher increase rates of the median and mean IS2 thickness could be attributed to both the increase in ridge fraction and ridge height.

In addition to the individual buoy comparison, we also compare the regional variations of SIT around the MOSAiC DN over a $50 \mathrm{~km}$ area surrounding the center of the SIMBA buoys network. The regionallyaveraged thermodynamic ice growth is calculated from the average of the 10 SIMBA buoys. Then the IS2 data around $50 \mathrm{~km}$ buffer area from the center of SIMBA buoy network are collected, and the variations of IS2 modal, median, and mean thickness are calculated (Fig. 10). Although the IS2 modal thickness underestimates the regionallyaveraged level ice thickness, it shows the lowest difference: RMSD $0.154 \mathrm{~m}$ and MBD $-0.150 \mathrm{~m}$. However, the median and mean overestimates the thickness of level ice with $0.253 \mathrm{~m}$ and $0.449 \mathrm{~m}$ of MBD, respectively (Table 3 ). Therefore, as similar to the individual comparisons, the IS2 modal thickness represents the thickness of level ice, but the mean and median also include the contributions from dynamic sea ice deformation. In terms of the ice growth rate, the IS2 mode measurement $(0.447 \mathrm{~cm} /$ day $)$ is the closest to the regional thermodynamic ice growth $(0.535 \mathrm{~cm} /$ day): only $-0.088 \mathrm{~cm} /$ day of difference. However, the IS2 median and mean thickness overestimates the thermodynamic ice growth by $0.148 \mathrm{~cm} /$ day and $0.244 \mathrm{~cm} /$ day, respectively

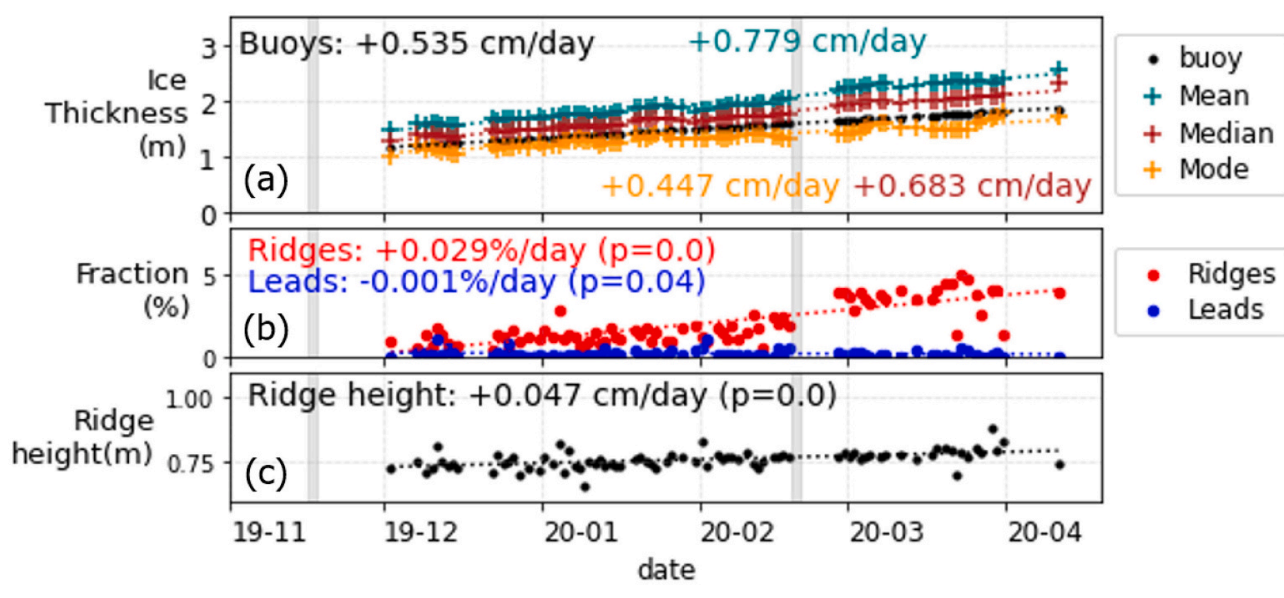

Fig. 10. (a) Averaged ice thickness of 10 SIMBA buoys (black line), IS2 modal thickness (orange crosses), IS2 median thickness (brown crosses), and IS2 mean thickness (green crosses) within $50 \mathrm{~km}$ buffer distance from the center of MOSAiC DN; (b) temporal variations of ridge fractions (red dots) and lead fractions (blue dots) in the $50 \mathrm{~km}$ buffer area; (c) temporal variations of ridge heights in the $50 \mathrm{~km}$ buffer area. Gray shading vertical bars indicate the heavy storm events in mid-November and mid-February. (For interpretation of the references to colour in this figure legend, the reader is referred to the web version of this article.) 

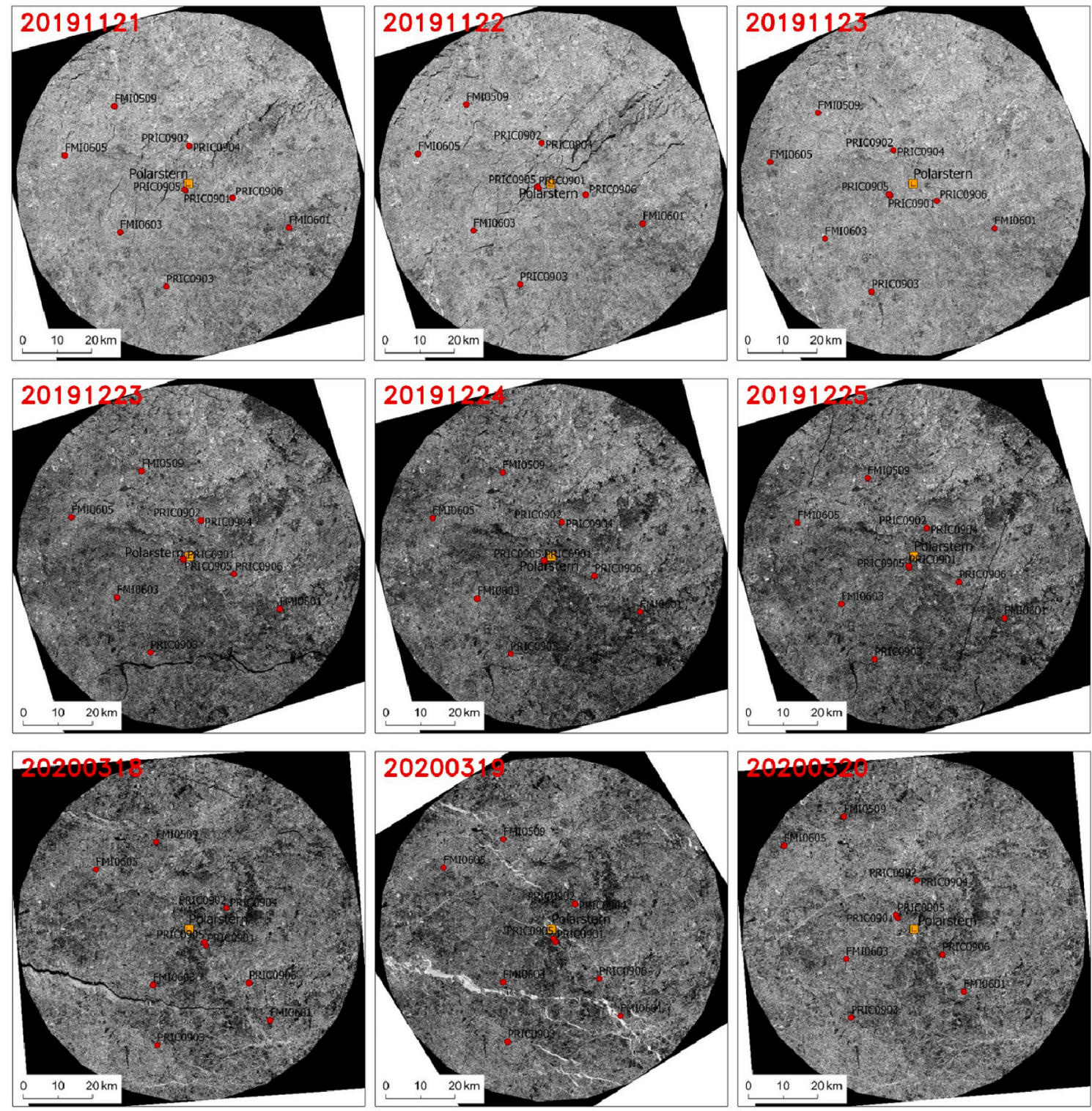

Fig. 11. Sentinel-1 HH band images of the $50 \mathrm{~km}$ buffer area from the Polarstern for November 21-23, 2019, December 23-25, 2019, and March 18-20, 2020. Sea ice leads (dark or bright elongated features) disappear in 2-3 days after they form, but general sea ice textures (i.e., overall distribution of dark and bright features) stay consistent in the successive days.

(Table 3). The comparison between the IS2 mode, median, and mean measurements implies that the dynamic thickening contributes to about $34.6 \%$ of the IS2-median increasing rate and $42.6 \%$ of the IS2-mean increasing rate, which agrees with the range of dynamic contributions estimated from the individual comparison.

As shown in the bottom two panels of Fig. 10, both ridge fraction and ridge height increased significantly around the $\sim 50 \mathrm{~km}$ MOSAiC DN area. However, the lead fraction does not show any significant increase or decrease trend during December to March, which agrees with the lead fraction observations from Krumpen et al. (2021). Therefore, the increase in ridge fraction and ridge height may contribute to the larger ice growth from the median and mean IS2 thickness.

\section{Discussion}

\subsection{SAR images around the buoys}

We visually explore the changes of sea ice condition around the MOSAiC DN by using the ESA (European Space Agency)'s Sentinel-1 synthetic aperture radar (SAR) images. These SAR images have been used to detect open water or thin ice on sea ice leads (Murashkin et al., 2018). Sea ice leads generally have low backscatter values on $\mathrm{HH}$ and HV bands because they have low surface roughness and reflectance (Longepe et al., 2019; Murashkin et al., 2018). However, open water on leads can also appear bright on $\mathrm{HH}$ band under high incidence angles because wind can roughen the water surface (Murashkin et al., 2018). In addition to this feature of backscatter or brightness, leads should have distinctive elongated shapes (Murashkin et al., 2018). Based on these features of sea ice leads, therefore, we can readily identify opening and closing of sea ice leads from the Sentinel-1 images.

Fig. 11 shows the Sentinel-1 HH band images with sea ice leads for some successive days in November, December, and March. As shown in these images, once leads form, they last only $\sim 2-3$ days and disappear because open water and thin ice areas on leads are refrozen quickly in the ice-growing season. However, while sea ice leads are such temporary features, ridges are accumulated features. In Fig. 11, while sea ice leads change fast even within one day, general sea ice textures (e.g. spatial distribution of bright or dark part) remain similar without significant 

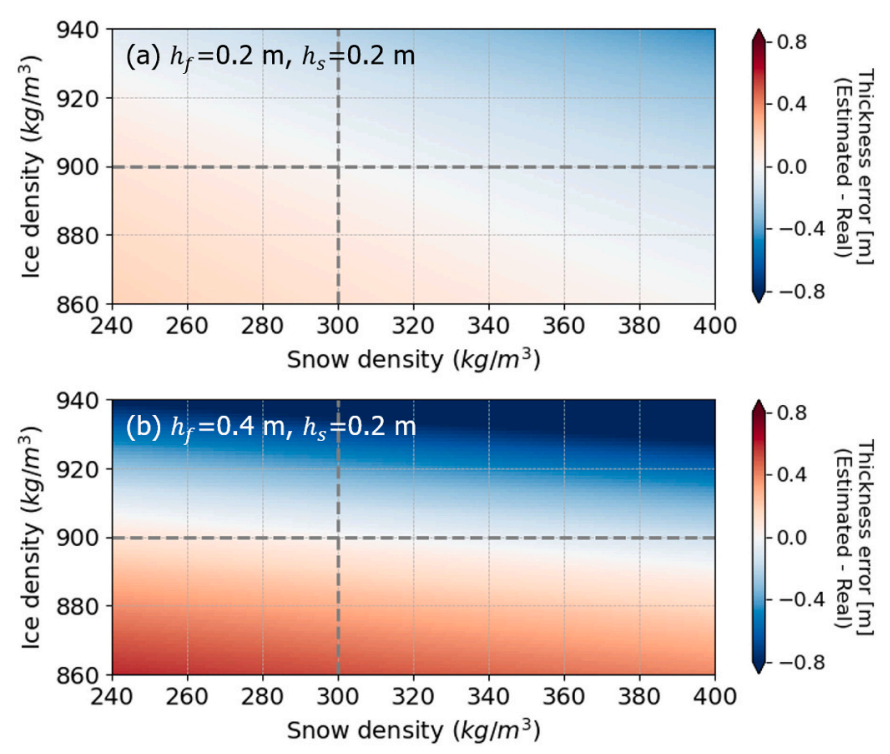

Fig. 12. Potential errors of the IS 2 thickness estimation due to various snow/ ice density conditions at (a) $h_{f}=0.2 \mathrm{~m}$, (b) $h_{f}=0.4 \mathrm{~m}$. The bold gray dashed lines indicate the assumed densities $\left(\rho_{s}=300 \mathrm{~kg} / \mathrm{m}^{3}, \rho_{i}=900 \mathrm{~kg} / \mathrm{m}^{3}\right)$.

changes. These ridge-like features would be steadily accumulated during the ice-growing season as the sea ice become compacted. We provide a short video clip of all Sentinenl-1 SAR images near the MOSAiC DN as auxiliary data with the manuscript.

\subsection{Uncertainty in IS2-buoy comparison}

Although we find that the IS2 modal thickness represents well the thermodynamic ice growth, we need to consider that there are some sources of uncertainties for the IS2-buoy comparison.

First, in terms of the buoy thickness estimation, the precision of the buoy measurement is $\sim 2 \mathrm{~cm}$ since the SIMBA string measures the temperature profile every $2 \mathrm{~cm}$. Second, when we estimate ice thickness from IS2 total freeboard, one of the major sources of uncertainty comes from the retrieval of snow depth from the IS2 freeboard. In this study, we employ the linear equations proposed by Kwok et al., 2020a to directly convert IS2 total freeboard into snow depth. Although this approach can be useful for predicting snow depth where only total freeboards are available and considering the impacts of sea ice deformation on snow depth, these linear regressions have $2.5-3.0 \mathrm{~cm}$ of standard errors. Additionally, the snow depths retrieved from IS2 freeboard potentially have a few centimeters of errors when compared with the snow depths from the OIB snow radar (Kwok et al., 2020a).

Another source of uncertainty can be introduced by the assumption of a constant density of snow, ice and water. When the IS2 freeboard is converted to ice thickness, snow, ice, and water density are assumed to be $300 \mathrm{~kg} / \mathrm{m}^{3}, 900 \mathrm{~kg} / \mathrm{m}^{3}$, and $1025 \mathrm{~kg} / \mathrm{m}^{3}$, respectively, because the insitu density measurements are not available for the individual buoys. Considering snow or ice density can vary temporally or spatially even in floe scales (Iacozza and Barber, 1999; King et al., 2020; Proksch et al., 2015; Sturm et al., 2002a; Warren et al., 1999), the variations of ice and snow densities can make a considerable difference on the thickness calculation from the IS2 freeboard. Indeed, the initial deployed sites of the buoys include the level ice and that close to ridges, the FYI and MYI, and the ice with a large range of thickness, which can lead to significant point-to-point differences in sea ice density and its seasonal variation. In addition, the spatial change in surface roughness would lead to different site-to-site snow accumulation processes (Wagner et al., 2021), and potentially different snow stratification and density.

In order to quantify the uncertainty of SIT estimation caused by this snow and ice density variation, the SIT is recalculated for different ice density and snow density conditions (Fig. 12). Based on the previous studies (Alexandrov et al., 2010; Sturm et al., 2002a; Timco and Frederking, 1996), the ice density was simulated from 860 to $940 \mathrm{~kg} / \mathrm{m}^{3}$, and snow density from 240 to $400 \mathrm{~kg} / \mathrm{m}^{3}$. Since the snow depth is nearly consistent for each individual buoy (Fig. 6a), we assume a consistent snow depth of $0.2 \mathrm{~m}$ and simulate the ice thickness for two different total freeboards: $0.2 \mathrm{~m}$ (autumn to early winter) and $0.4 \mathrm{~m}$ (late winter to spring). As shown in Fig. 12, if the ice density is lower than $900 \mathrm{~kg} / \mathrm{m}^{3}$, the ice thickness would be overestimated by IS2 compared to the real ice thickness. On the contrary, if the ice density is higher than $900 \mathrm{~kg} / \mathrm{m}^{3}$, the thickness would be underestimated by IS2. In addition, the IS2derived thickness is overestimated if the real snow density is lower than $300 \mathrm{~kg} / \mathrm{m}^{3}$, and vice versa. Since these uncertainties increase with a larger freeboard, ice thickness in later winter could be more affected by snow and ice density. Moreover, the IS2-derived thickness is more sensitive to the ice density variations than the snow density variations.

In Fig. 8a, FMI0601 and PRIC0903 show somewhat different patterns with the other buoys: the mode, median, and mean IS2 thickness
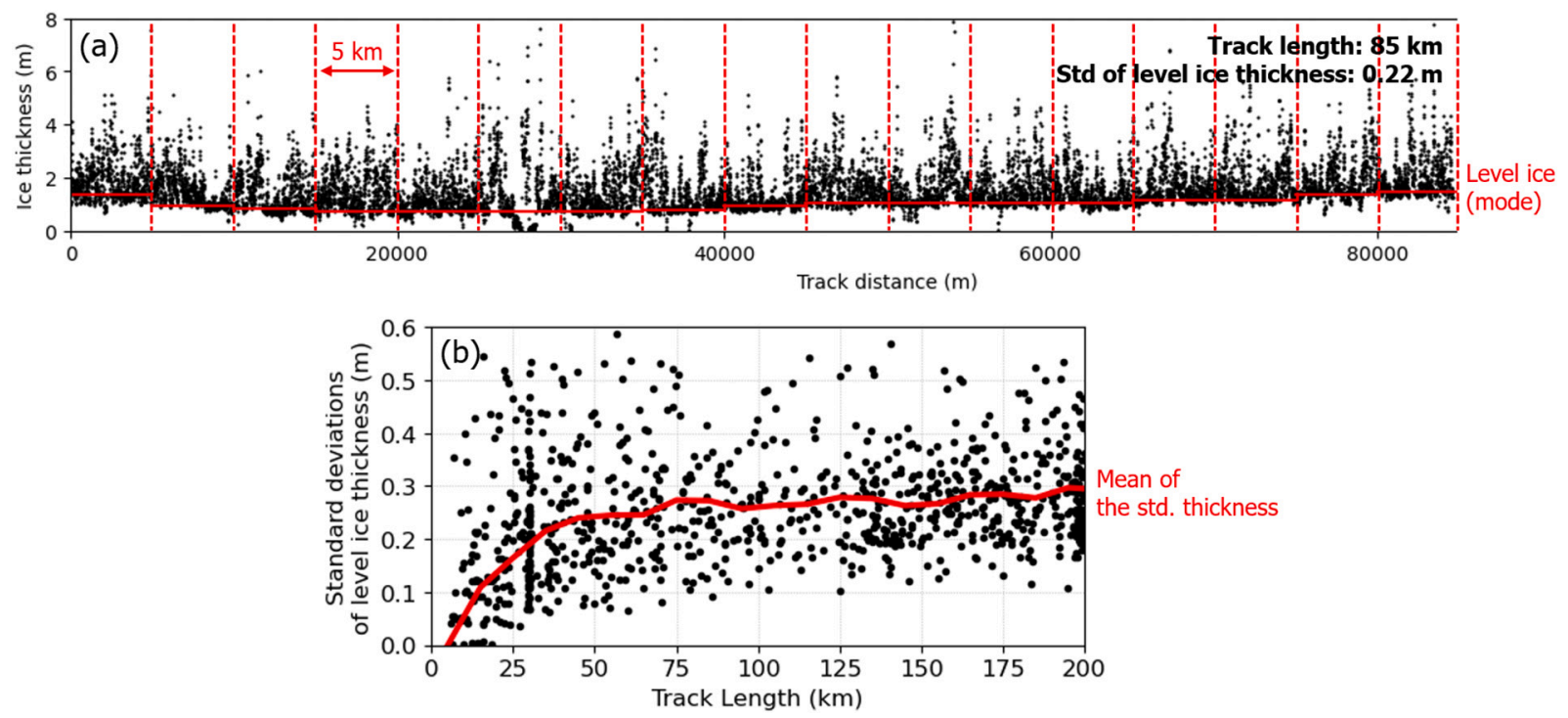

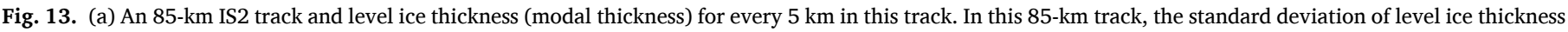
is $0.22 \mathrm{~m}$; (b) Standard deviation of level ice thickness by track length. 
measurements underestimate ice thickness so the mean shows the lowest bias with the buoy ice thickness. Considering that these two buoys are deployed over the sites with the relatively large initial ice thickness close to the ridge (Fig. 6b), these sites might have different snow or ice density conditions with the other buoys. In addition, according to Kwok and Cunningham (2008), climatological snow density continuously increase from $\sim 250 \mathrm{~kg} / \mathrm{m}^{3}$ in November to $\sim 350 \mathrm{~kg} / \mathrm{m}^{3}$ in March over the Arctic. Considering the increase of snow density during the ice-growing season, there is a possibility that IS2 overestimates ice thickness in early winter and underestimates in late winter; therefore, IS2 could underestimate overall ice growth. This can explain the negative bias of IS2-derived ice growth in Table 2 and Table 3.

Another possible source of uncertainty is the spatiotemporal discrepancy between IS2 tracks and buoy deployment site. In this study, we assume that the modal IS2 thickness represents level ice thickness within the $20 \mathrm{~km}$ buffer area from the buoy deployment site. Although we collect the IS2 data within $12 \mathrm{~h}$ of time gaps from the buoys, the buoys drifted with $\sim 10.35 \mathrm{~km} /$ day on average. Since the buoy and IS2 measurements are not exactly co-located in space and simultaneous in time, therefore, the level ice thickness measured by IS2 could be different from the buoy ice thickness. In addition, given that the IS2 data is track data, they only represent a certain part of the $20 \mathrm{~km}$ circle, not the entire circle area. Thus, the sampled area where the IS2 tracks pass through is different whenever the overlapped IS2 data are sampled. For example, as shown in Fig. 4, the IS2 tracks in the $20 \mathrm{~km}$ buffer have different coverage area on November 13 and March 30.

Indeed, the thickness of level ice can vary over a few $\mathrm{km}$ scales. Fig. 13a shows one 85-km IS2 track. We calculate the modal thickness every $5 \mathrm{~km}$, and this $5-\mathrm{km}$ modal ice thickness changes even within a single IS2 track (standard deviation of the 5-km modal ice thickness $0.22 \mathrm{~m}$ for this $85-\mathrm{km}$ track). As shown in Fig. 13b, the standard deviation of the level ice thickness generally increases with a longer track distance. For a track distance longer than $50 \mathrm{~km}$, however, the standard deviations stays consistent value of $\sim 0.25 \mathrm{~m}$. Thus, if the sampled IS2 track and the buoy site are not exactly coincident, IS2 and buoy measurements are likely to be different. This issue of different sampling principle between IS2 and buoy can be mitigated by combining and averaging multiple data. In Section 4.2, both individual buoy comparison ( $\sim 20 \mathrm{~km}$ scale) and regional average of the 10 buoys ( $\sim 50 \mathrm{~km}$ scale) are checked. As shown in Table 1, Table 2, and Table 3, the regionallyaveraged comparison has a lower RMSD and MBD than the individual comparison. This also implies that the deployment scale of the MOSAiC SIMBA buoys is suitable for comparison with the IS2 measurements.

\subsection{Outlooks for the application of IS2}

This study demonstrates the ability of IS2 to capture thermodynamic and dynamic ice thickening based on its high resolution. However, for a clearer explanation of the thermodynamic and dynamic sea ice thickening processes in our study area (central Arctic Ocean across the Transpolar Drift Stream), various data sources are required: e.g., divergence, convergence, or shear stress of sea ice, ocean temperature, air temperature, ocean current, wind direction, etc. A series of various satellite data or other field observations from the MOSAiC expedition (e. g. drilling data, airborne observations, and underwater robot observations) would provide detailed information about these factors. Once these data are combined to analyze, which is ongoing, they will help us better understand the mechanism of thermodynamic and dynamic ice thickening over the Arctic Ocean. Moreover, there might be a significant difference in sea ice conditions between our study area and other regions (e.g. the Beaufort Gyre) and by season. Therefore, by further examining the spatiotemporal changes in thermodynamic or dynamic ice thickening for different regions and years using IS2, we will be able to characterize and compare how various atmospheric and oceanographic factors affect the sea ice thickening processes for different regions and seasons.

\section{Summary and conclusions}

This study demonstrates the ability of IS2 for measuring the seasonal variations of ice thickness and distinguishing thermodynamic and dynamic ice thickening through the comparison with the MOSAiC SIMBA buoys. While most of the previous studies focused on the validation of the satellite freeboard or thickness value itself based on an airborne measurement in a short time period (one or a few days) (e.g. OIB), we focus on assessing the temporal variations of ice thickness and ice thickening during the ice-growing season, by taking advantage of the long-term and continuous measurements from the IMB buoy data. Our results show that IS2 is able to detect the increases of sea ice thickness during the ice-growing season of the Arctic.

In addition, it is noted that the three different measurements of IS2 thickness (i.e. mode, median, and mean) show significant differences in estimating ice thickness and ice growth. The IS2 modal thickness shows the least difference (RMSD $0.341 \mathrm{~m}$ and MBD $-0.169 \mathrm{~m}$ ) with the buoy ice thickness. However, the median and mean IS2 thickness overestimate the buoy ice thickness by around $0.190 \mathrm{~m}$ and $0.433 \mathrm{~m}$, respectively. In addition, while the ice growth estimated by the IS2 modal thickness shows a similar increasing rate with the thermodynamic ice growth estimated by the buoys $(-0.054 \mathrm{~cm} /$ day of MBD), the median and mean IS2 thickness are greater than the thermodynamic ice growth by $0.114 \mathrm{~cm} /$ day and $0.198 \mathrm{~cm} /$ day, respectively. Consequently, this result implies that the IS2 modal thickness represents the thermodynamic ice growth. On the other hand, the median and mean IS2 measurements explain the dynamic contributions from sea ice deformation, accounting for averagely $26 \%$ and $34 \%$ of the total increasing rate, respectively.

Indeed, the IS2 measurements around $\sim 50 \mathrm{~km}$ area from the MOSAiC CO show that ridge fraction increased from $<2 \%$ in November to $\sim 4 \%$ in late March, with about $+0.029 \%$ /day of increasing rate. Along with the increase of ridge fraction, ridge height also shows a significant increase trend with $+0.047 \mathrm{~cm} /$ day of increasing rate. However, lead fraction does not show any significant trend during the same period. This is because sea ice leads appear only $2-3$ days and they are refrozen quickly during the ice-growing season, whereas ridges are generally accumulated. The weathering of ice ridges is obviously weaker than the cumulative strengthening of dynamics. Both the temporary formation of leads and long-term existence of ridges are observed in a series of the Sentinel-1 SAR HH band images.

Despite the good correlation between IS2 and buoy data in estimating sea ice thickness and its growth rate, we need to consider various sources of uncertainties. First, buoy measurements have $\sim 2 \mathrm{~cm}$ of implicit uncertainty. Second, there can be significant uncertainties in converting IS2 total freeboard into ice thickness, which is associated with the retrieval of snow depth, snow density and ice density. Finally, there is a spatiotemporal discrepancy between IS2 and buoy data: the sampling time and location of the IS2 data and buoys are not exactly the same due to the drift of sea ice. Since the thickness of level ice can vary within a few $\mathrm{km}$ scale, the comparison between IS2 and buoy has inevitable uncertainties. Based on the findings of this study, IS2 will be able to provide important clues for the thermodynamic and dynamic ice thickening processes over the Arctic Ocean.

Supplementary data to this article can be found online at https://doi. org/10.1016/j.rse.2021.112730.

\section{Declaration of Competing Interest}

The authors declare that they have no known competing financial interests or personal relationships that could have appeared to influence the work reported in this paper.

\section{Acknowledgements}

Buoy data used in this manuscript were produced as part of the 
international Multidisciplinary drifting Observatory for the Study of the Arctic Climate (MOSAiC) with the tag MOSAiC20192020. All data are archived in the MOSAiC Central Storage (MCS) and will be available on PANGAEA after finalization of the respective datasets according to the MOSAiC data policy. We would like to thank the National Aeronautics and Space Administration (NASA) for processing and providing ICESat-2 data. Funding support to Y. Koo, H. Xie, A. Mestas was from the U.S. NSF (1835784) grant. R. Lei was supported by the National Key Research and Development Program (2018YFA0605903 and 2016YFC1400303). Y. Cheng was supported by the Key Research Program of Frontier Sciences, Chinese Academy of Sciences (ZDBS-LY-DQC010). B. Cheng was supported by the European Union's Horizon 2020 research and innovation programme (727890 - INTAROS). We give special thanks to cruise leader Thomas Krumpen, all the crew and pilots of the Akademik Fedorov, and the entire science team of the MOSAiC expedition. Critical reviews and constructional comments from two anonymous reviewers to improve the quality of this manuscript are greatly appreciated.

\section{References}

Ackley, S.F., Xie, H., Tichenor, E.A., 2015. Ocean heat flux under Antarctic sea ice in the Bellingshausen and Amundsen Seas: two case studies. Ann. Glaciol. 56, 200-210. https://doi.org/10.3189/2015AoG69A890.

Ackley, S.F., Perovich, D.K., Maksym, T., Weissling, B., Xie, H., 2020. Surface flooding of Antarctic summer sea ice. Ann. Glaciol. 61, 117-126. https://doi.org/10.1017/ aog.2020.22.

Alexandrov, V., Sandven, S., Wahlin, J., Johannessen, O.M., 2010. The relation between sea ice thickness and freeboard in the Arctic. Cryosphere 4, 373-380. https://doi. org/10.5194/tc-4-373-2010.

Budikova, D., 2009. Role of Arctic sea ice in global atmospheric circulation: a review. Glob. Planet. Chang. 68, 149-163. https://doi.org/10.1016/j. gloplacha.2009.04.001.

Cavalieri, D.J., Parkinson, C.L., 2012. Arctic sea ice variability and trends, 1979-2010. Cryosphere 6, 881-889. https://doi.org/10.5194/tc-6-881-2012.

Cheng, Y., Cheng, B., Zheng, F., Vihma, T., Kontu, A., Yang, Q., Liao, Z., 2020. Air/snow, snow/ice and ice/water interfaces detection from high-resolution vertical temperature profiles measured by ice mass-balance buoys on an Arctic lake. Ann. Glaciol. 1-11. https://doi.org/10.1017/aog.2020.51.

Duncan, K., Farrell, S.L., Connor, L.N., Richter-Menge, J., Hutchings, J.K., Dominguez, R., 2018. High-resolution airborne observations of sea-ice pressure ridge sail height. Ann. Glaciol. 59, 137-147. https://doi.org/10.1017/aog.2018.2.

Duncan, K., Farrell, S.L., Hutchings, J., Richter-Menge, J., 2020. Late winter observations of sea ice pressure ridge sail height. IEEE Geosci. Remote Sens. Lett. 1-5. https://doi. org/10.1109/lgrs.2020.3004724.

ESA, 2019. CryoSat-2 Product Handbook. ESA.

Farrell, S.L., Kurtz, N., Connor, L.N., Elder, B.C., Leuschen, C., Markus, T., McAdoo, D.C., Panzer, B., Richter-Menge, J., Sonntag, J.G., 2012. A first assessment of IceBridge Snow and Ice thickness data over arctic sea ice. IEEE Trans. Geosci. Remote Sens. 50, 2098-2111. https://doi.org/10.1109/TGRS.2011.2170843.

Farrell, S.L., Duncan, K., Buckley, E.M., Richter-Menge, J., Li, R., 2020. Mapping sea ice surface topography in high fidelity with ICESat-2. Geophys. Res. Lett. 47 https://doi. org/10.1029/2020GL090708.

Hansen, E., Gerland, S., Granskog, M.A., Pavlova, O., Renner, A.H.H., Haapala, J., Løyning, T.B., Tschudi, M., 2013. Thinning of Arctic sea ice observed in Fram Strait: 1990-2011. J. Geophys. Res. Ocean 118, 5202-5221. https://doi.org/10.1002/ jgrc. 20393.

Hibler, W.D., 1979. A dynamic thermodynamic sea ice model. J. Phys. Oceanogr. 9, 815-846. https://doi.org/10.1175/1520-0485(1979)009<0815:ADTSIM > 2.0.CO;2.

Hoppmann, M., Nicolaus, M., Hunkeler, P.A., Heil, P., Behrens, L.-K., König-Langlo, G., Gerdes, R., 2015. Seasonal evolution of an ice-shelf influenced fast-ice regime, derived from an autonomous thermistor chain. J. Geophys. Res. Ocean 120, 1703-1724. https://doi.org/10.1002/2014JC010327.

Iacozza, J., Barber, D.G., 1999. An examination of the distribution of snow on sea-ice. Atmosphere-Ocean 37, 21-51. https://doi.org/10.1080/07055900.1999.9649620.

Itkin, P., Spreen, G., Hvidegaard, S.M., Skourup, H., Wilkinson, J., Gerland, S., Granskog, M.A., 2018. Contribution of deformation to sea ice mass balance: a case study from an N-ICE2015 storm. Geophys. Res. Lett. 45, 789-796. https://doi.org/ 10.1002/2017GL076056.

Jackson, K., Wilkinson, J., Maksym, T., Meldrum, D., Beckers, J., Haas, C., Mackenzie, D. 2013. A novel and low-cost sea ice mass balance buoy. J. Atmos. Ocean. Technol. 30, 2676-2688. https://doi.org/10.1175/JTECH-D-13-00058.1.

Jaiser, R., Dethloff, K., Handorf, D., Rinke, A., Cohen, J., 2012. Impact of sea ice cover changes on the northern hemisphere atmospheric winter circulation. Tellus Ser. A Dyn. Meteorol. Oceanogr. 64, 1-11. https://doi.org/10.3402/tellusa.v64i0.11595.

King, J., Howell, S., Brady, M., Toose, P., Derksen, C., Haas, C., Beckers, J., 2020. Localscale variability of snow density on Arctic sea ice. Cryosphere Discuss. 1-29 https:// doi.org/10.5194/tc-2019-305.

Krumpen, T., Birrien, F., Kauker, F., Rackow, T., von Albedyll, L., Angelopoulos, M., Belter, H.J., Bessonov, V., Damm, E., Dethloff, K., Haapala, J., Haas, C., Hendricks, S., Hoelemann, J., Hoppmann, M., Kaleschke, L., Karcher, M.,
Kolabutin, Nikolai, Lenz, J., Morgenstern, A., Nicolaus, M., Nixdorf, U., Petrovsky, T., Rabe, B., Rabenstein, L., Rex, M., Ricker, R., Rohde, J., Shimanchuk, E., Singha, S., Smolyanitsky, V., Sokolov, V., Stanton, T., Timofeeva, A., Tsamados, M., 2020. The MOSAiC ice floe: sediment-laden survivor from the Siberian shelf. Cryosphere Discuss. 1-20 https://doi.org/10.5194/tc-202064.

Krumpen, T., von Albedyll, L., Goessling, H.F., Hendricks, S., Juhls, B., Spreen, G., Willmes, S., Belter, H.J., Dethloff, K., Haas, C., Kaleschke, L., Katlein, C., TianKunze, X., Ricker, R., Rostosky, P., Rueckert, J., Singha, S., Sokolova, J., 2021. The MOSAiC Drift: ice conditions from space and comparison with previous years. Cryosphere Discuss. 2021, 1-35. https://doi.org/10.5194/tc-2021-80.

Kwok, R., 2010. Satellite remote sensing of sea-ice thickness and kinematics: a review. J. Glaciol. 56, 1129-1140. https://doi.org/10.3189/002214311796406167.

Kwok, R., 2018. Arctic sea ice thickness, volume, and multiyear ice coverage: losses and coupled variability (1958-2018). Environ. Res. Lett. 13 https://doi.org/10.1088/ 1748-9326/aae3ec.

Kwok, R., Cunningham, G.F., 2008. ICESat over Arctic sea ice: estimation of snow depth and ice thickness. J. Geophys. Res. Ocean 113, 1-17. https://doi.org/10.1029/ 2008JC004753.

Kwok, R., Cunningham, G.F., 2015. Variability of arctic sea ice thickness and volume from CryoSat-2. Philos. Trans. R. Soc. A Math. Phys. Eng. Sci. 373 https://doi.org/ 10.1098/rsta.2014.0157.

Kwok, R., Kacimi, S., Markus, T., Kurtz, N.T., Studinger, M., Sonntag, J.G., Manizade, S. S., Boisvert, L.N., Harbeck, J.P., 2019a. ICESat-2 surface height and sea ice freeboard assessed with ATM Lidar acquisitions from operation IceBridge. Geophys. Res. Lett. 46, 11228-11236. https://doi.org/10.1029/2019GL084976.

Kwok, R., Markus, T., Kurtz, N.T., Petty, A.A., Neumann, T.A., Farrell, S.L., Cunningham, G.F., Hancock, D.W., Ivanoff, A., Wimert, J.T., 2019b. Surface height and sea ice freeboard of the Arctic Ocean from ICESat-2: characteristics and early results. J. Geophys. Res. Ocean 124, 6942-6959. https://doi.org/10.1029/ 2019JC015486.

Kwok, R., Kacimi, S., Webster, M.A., Kurtz, N.T., Petty, A.A., 2020a. Arctic snow depth and sea ice thickness from ICESat-2 and CryoSat-2 freeboards: a first examination. J. Geophys. Res. Ocean 125, 1-19. https://doi.org/10.1029/2019JC016008.

Kwok, R., Petty, A., Bagnardi, M., Kurtz, N., Cunningham, G., Ivanoff, A., 2020b. Refining the sea surface identification approach for determining freeboards in the ICESat-2 sea ice products. Cryosphere Discuss. 1-18 https://doi.org/10.5194/tc2020-174.

Kwok, R., Cunningham, G., Hancock, D., Ivanoff, A., Wimert, J., 2021. Algorithm Theoretical Basis Document (ATBD): Sea Ice Products.

Laxon, S., Peacock, H., Smith, D., 2003. High interannual variability of sea ice thickness in the Arctic region. Nature 425, 947-950. https://doi.org/10.1038/nature02050.

Laxon, S.W., Giles, K.A., Ridout, A.L., Wingham, D.J., Willatt, R., Cullen, R., Kwok, R., Schweiger, A., Zhang, J., Haas, C., Hendricks, S., Krishfield, R., Kurtz, N., Farrell, S., Davidson, M., 2013. CryoSat-2 estimates of Arctic sea ice thickness and volume. Geophys. Res. Lett. 40, 732-737. https://doi.org/10.1002/grl.50193.

Lecomte, O., Fichefet, T., Vancoppenolle, M., Domine, F., Massonnet, F., Mathiot, P., Morin, S., Barriat, P.Y., 2013. On the formulation of snow thermal conductivity in large-scale sea ice models. J. Adv. Model. Earth Syst. 5, 542-557. https://doi.org/ 10.1002/jame.20039.

Lei, R., Cheng, B., Heil, P., Vihma, T., Wang, J., Ji, Q., Zhang, Z., 2018. Seasonal and interannual variations of sea ice mass balance from the Central Arctic to the Greenland Sea. J. Geophys. Res. Ocean 123, 2422-2439. https://doi.org/10.1002/ 2017JC013548.

Leppäranta, M., 1993. A review of analytical models of sea-ice growth. AtmosphereOcean 31, 123-138. https://doi.org/10.1080/07055900.1993.9649465.

Levermann, A., Mignot, J., Nawrath, S., Rahmstorf, S., 2007. The role of northern sea ice cover for the weakening of the thermohaline circulation under global warming. J. Clim. 20, 4160-4171. https://doi.org/10.1175/JCLI4232.1.

Li, M., Ke, C.Q., Xie, H., Miao, X., Shen, X., Xia, W., 2020. Arctic sea ice thickness retrievals from CryoSat-2: seasonal and interannual comparisons of three different products. Int. J. Remote Sens. 41, 152-170. https://doi.org/10.1080/ 01431161.2019.1637961.

Liao, Z., Cheng, B., Zhao, J.C., Vihma, T., Jackson, K., Yang, Q., Yang, Y., Zhang, L., Li, Z., Qiu, Y., Cheng, X., 2019. Snow depth and ice thickness derived from SIMBA ice mass balance buoy data using an automated algorithm. Int. J. Digit. Earth 12, 962-979. https://doi.org/10.1080/17538947.2018.1545877.

Lindsay, R., Schweiger, A., 2015. Arctic sea ice thickness loss determined using subsurface, aircraft, and satellite observations. Cryosphere 9, 269-283. https://doi. org/10.5194/tc-9-269-2015.

Liu, J., Curry, J.A., Wang, H., Song, M., Horton, R.M., 2012. Impact of declining Arctic sea ice on winter snowfall. Proc. Natl. Acad. Sci. U. S. A. 109, 4074-4079. https:// doi.org/10.1073/pnas.1114910109.

Longepe, N., Thibaut, P., Vadaine, R., Poisson, J.C., Guillot, A., Boy, F., Picot, N., Borde, F., 2019. Comparative evaluation of sea ice lead detection based on SAR imagery and altimeter data. IEEE Trans. Geosci. Remote Sens. 57, 4050-4061. https://doi.org/10.1109/TGRS.2018.2889519.

Magruder, L.A., Brunt, K.M., Alonzo, M., 2020. Early icesat-2 on-orbit geolocation validation using ground-based corner cube retro-reflectors. Remote Sens. 12, 1-21. https://doi.org/10.3390/rs12213653.

Markus, T., Neumann, T., Martino, A., Abdalati, W., Brunt, K., Csatho, B., Farrell, S., Fricker, H., Gardner, A., Harding, D., Jasinski, M., Kwok, R., Magruder, L., Lubin, D., Luthcke, S., Morison, J., Nelson, R., Neuenschwander, A., Palm, S., Popescu, S., Shum, C.K., Schutz, B.E., Smith, B., Yang, Y., Zwally, J., 2017. The Ice, Cloud, and land Elevation Satellite-2 (ICESat-2): science requirements, concept, and 
implementation. Remote Sens. Environ. 190, 260-273. https://doi.org/10.1016/j. rse.2016.12.029.

Meier, W.N., 2017. Losing Arctic sea ice: observations of the recent decline and the longterm context. In: Sea Ice. Wiley Online Books. https://doi.org/10.1002/ 9781118778371.ch11.

Murashkin, D., Spreen, G., Huntemann, M., Dierking, W., 2018. Method for detection of leads from Sentinel-1 SAR images. Ann. Glaciol. 59, 124-136. https://doi.org/ 10.1017/aog.2018.6.

Neumann, T.A., Martino, A.J., Markus, T., Bae, S., Bock, M.R., Brenner, A.C., Brunt, K.M. Cavanaugh, J., Fernandes, S.T., Hancock, D.W., Harbeck, K., Lee, J., Kurtz, N.T., Luers, P.J., Luthcke, S.B., Magruder, L., Pennington, T.A., Ramos-Izquierdo, L., Rebold, T., Skoog, J., Thomas, T.C., 2019. The ice, cloud, and land elevation satellite - 2 mission: a global geolocated photon product derived from the advanced topographic laser altimeter system. Remote Sens. Environ. 233, 111325. https://doi. org/10.1016/j.rse.2019.111325.

Park, H., Watanabe, E., Kim, Y., Polyakov, I., Oshima, K., Zhang, X., Kimball, J.S., Yang, D., 2020. Increasing riverine heat influx triggers Arctic sea ice decline and oceanic and atmospheric warming. Sci. Adv. 6, 1-8. https://doi.org/10.1126/ SCIADV.ABC4699.

Perovich, D.K., Grenfell, T.C., Richter-Menge, J.A., Light, B., Tucker III, W.B., Eicken, H., 2003. Thin and thinner: sea ice mass balance measurements during SHEBA. J. Geophys. Res. Ocean 108. https://doi.org/10.1029/2001JC001079.

Petty, A.A., Tsamados, M.C., Kurtz, N.T., Farrell, S.L., Newman, T., Harbeck, J.P., Feltham, D.L., Richter-Menge, J.A., 2016. Characterizing Arctic sea ice topography using high-resolution IceBridge data. Cryosphere 10, 1161-1179. https://doi.org/ 10.5194/tc-10-1161-2016.

Petty, Alek A., Bagnardi, M., Kurtz, N., Tilling, R., Fons, S., Armitage, T., Horvat, C. 2020a. Assessment of ICESat-2 sea ice surface classification with Sentinel-2 imagery: implications for freeboard and new estimates of lead and floe geometry. Earth Sp. Sci. 2.

Petty, Alek A., Kurtz, N.T., Kwok, R., Markus, T., Neumann, T.A., 2020b. Winter Arctic Sea ice thickness from ICESat-2 freeboards. J. Geophys. Res. Ocean 125, 1-28. https://doi.org/10.1029/2019jc015764.

Proksch, M., Löwe, H., Schneebeli, M., 2015. Density, specific surface area, and correlation length of snow measured by high-resolution penetrometry. J. Geophys. Res. Earth Surf. 120, 346-362. https://doi.org/10.1002/2014JF003266.

Provost, C., Sennéchael, N., Miguet, J., Itkin, P., Rösel, A., Koenig, Z., VillacierosRobineau, N., Granskog, M.A., 2017. Observations of flooding and snow-ice formation in a thinner Arctic sea-ice regime during the N-ICE2015 campaign: influence of basal ice melt and storms. J. Geophys. Res. Ocean 122, 7115-7134. https://doi.org/10.1002/2016JC012011.

Provost, C., Sennéchael, N., Sirven, J., 2019. Contrasted summer processes in the sea ice for two neighboring floes north of $84^{\circ} \mathrm{N}$ : surface and basal melt and false bottom formation. J. Geophys. Res. Ocean 124, 3963-3986. https://doi.org/10.1029/ 2019JC015000.

Rack, W., Price, D., Haas, C., Langhorne, P.J., Leonard, G.H., 2021. Sea ice thickness in the Western Ross Sea. Geophys. Res. Lett. 48 https://doi.org/10.1029/ 2020GL090866.

Richter-Menge, J.A., Perovich, D.K., Elder, B.C., Claffey, K., Rigor, I., Ortmeyer, M., 2006. Ice mass-balance buoys: a tool for measuring and attributing changes in the thickness of the Arctic sea-ice cover. Ann. Glaciol. 44, 205-210. https://doi.org/ 10.3189/172756406781811727.

Screen, J.A., 2013. Influence of Arctic sea ice on European summer precipitation. Environ. Res. Lett. 8 https://doi.org/10.1088/1748-9326/8/4/044015.

Shalina, E.V., Sandven, S., 2018. Snow depth on Arctic sea ice from historical in situ data. Cryosphere 12, 1867-1886. https://doi.org/10.5194/tc-12-1867-2018.

Shupe, M.D., Rex, M., Dethloff, K., Damm, E., Fong, A.A., Gradinger, R., Heuzé, C., Loose, B., Makarov, A., Maslowski, W., Nicolaus, M., Perovich, D., Rabe, B., Rinke, A., Sokolov, V., Sommerfeld, A., 2020. Arctic Report Card 2020: The MOSAiC
Expedition: A Year Drifting with the Arctic Sea Ice. Arctic Report Card. https://doi. org $/ 10.25923 / 9 g 3 v-x h 92$.

Simmonds, I., 2015. Comparing and contrasting the behaviour of Arctic and Antarctic sea ice over the 35 year period 1979-2013. Ann. Glaciol. 56, 18-28. https://doi.org/ 10.3189/2015AoG69A909.

Stroeve, J., Notz, D., 2018. Changing state of Arctic sea ice across all seasons. Environ. Res. Lett. 13 https://doi.org/10.1088/1748-9326/aade56.

Sturm, M., Holmgren, J., Perovich, D.K., 2002a. Winter snow cover on the sea ice of the Arctic Ocean at the Surface Heat Budget of the Arctic Ocean (SHEBA): temporal evolution and spatial variability. J. Geophys. Res. C Ocean 107, 1-17. https://doi. org/10.1029/2000jc000400.

Sturm, M., Perovich, D.K., Holmgren, J., 2002b. Thermal conductivity and heat transfer through the snow on the ice of the Beaufort Sea. J. Geophys. Res. Ocean 107. https://doi.org/10.1029/2000jc000409.

Tan, B., Li, Z.J., Lu, P., Haas, C., Nicolaus, M., 2012. Morphology of sea ice pressure ridges in the northwestern Weddell Sea in winter. J. Geophys. Res. Ocean 117, 1-13. https://doi.org/10.1029/2011JC007800.

Tian, L., Xie, H., Ackley, S.F., Tinto, K.J., Bell, R.E., Zappa, C.J., Gao, Y., MestasNuñez, A.M., 2020. Sea Ice Freeboard in the Ross Sea from Airborne Altimetry IcePod 2016-2017 and a comparison with IceBridge 2013 and ICESat 2003-2008. Remote Sens. https://doi.org/10.3390/rs12142226.

Tilling, R.L., Ridout, A., Shepherd, A., 2018. Estimating Arctic sea ice thickness and volume using CryoSat-2 radar altimeter data. Adv. Sp. Res. 62, 1203-1225. https:// doi.org/10.1016/j.asr.2017.10.051.

Tilling, R., Kurtz, N.T., Bagnardi, M., Petty, A.A., Kwok, R., 2020. Detection of melt ponds on Arctic summer sea ice from ICESat-2. Geophys. Res. Lett. 47, 1-10. https:// doi.org/10.1029/2020GL090644.

Timco, G.W., Frederking, R.M.W., 1996. A review of sea ice density. Cold Reg. Sci. Technol. 24, 1-6. https://doi.org/10.1016/0165-232X(95)00007-X.

Wagner, D.N., Shupe, M.D., Persson, O.G., Uttal, T., Frey, M.M., Kirchgaessner, A., Schneebeli, M., Jaggi, M., Macfarlane, A.R., Itkin, P., Arndt, S., Hendricks, S., Krampe, D., Ricker, R., Regnery, J., Kolabutin, N., Shimanshuck, E., Oggier, M., Raphael, I., Lehning, M., 2021. Snowfall and snow accumulation processes during the MOSAiC winter and spring season. Cryosphere Discuss. 2021, 1-48. https://doi. org/10.5194/tc-2021-126.

Wang, X., Key, J., Kwok, R., Zhang, J., 2016. Comparison of Arctic sea ice thickness from satellites, aircraft, and PIOMAS data. Remote Sens. 8, 1-17. https://doi.org/ 10.3390/rs8090713.

Warren, S.G., Rigor, I.G., Untersteiner, N., Radionov, V.F., Bryazgin, N.N., Aleksandrov, Y.I., Colony, R., 1999. Snow depth on Arctic sea ice. J. Clim. 12, 1814-1829. https://doi.org/10.1175/1520-0442(1999)012<1814:SDOASI >2.0.CO; 2.

Xiao, F., Li, F., Zhang, S., Li, J., Geng, T., Xuan, Y., 2020. Estimating arctic sea ice thickness with cryosat-2 altimetry data using the least squares adjustment method. Sensors 20, 1-18. https://doi.org/10.3390/s20247011.

Xiao, F., Zhang, S., Li, J., Geng, T., Xuan, Y., Li, F., 2021. Arctic sea ice thickness variations from CryoSat-2 satellite altimetry data. Sci. China Earth Sci. https://doi. org/10.1007/s11430-020-9777-9.

Zhang, J., Rothrock, D., Steele, M., 2000. Recent changes in Arctic Sea ice: the interplay between ice dynamics and thermodynamics. J. Clim. 13, 3099-3114. https://doi. org /10.1175/1520-0442(2000)013<3099:RCIASI > 2.0.CO;2.

Zuo, G., Dou, Y., Lei, R., 2018. Discrimination algorithm and procedure of snow depth and sea ice thickness determination using measurements of the vertical ice temperature profile by the ice-tethered buoys. Sensors 18 , 4162. https://doi.org/ $10.3390 / \mathrm{s} 18124162$.

Zwally, H.J., Schutz, B., Abdalati, W., Abshire, J., Bentley, C., Brenner, A., Bufton, J., Dezio, J., Hancock, D., Harding, D., Herring, T., Minster, B., Quinn, K., Palm, S., Spinhirne, J., Thomas, R., 2002. ICESat's laser measurements of polar ice, atmosphere, ocean, and land. J. Geodyn. 34, 405-445. https://doi.org/10.1016/ S0264-3707(02)00042-X. 